Herger Csabáné

DOI: 10.15170/DIKE.2018.02.01.03

habilitált egyetemi docens

PTE ÁJK

\title{
A Pécsi Közjegyzői Kamara 1938 és 1945 között
}

\section{The Notary Chamber of Pécs between 1938 and 1945}

The writings of the Notary Chamber of Pécs are important documents of the epoch between 1938 and 1945. In particular, the word-for-word reports of the annual ordinary general meetings reveal the reactions of the highly educated chamber members to the historical and political changes. It is also important for legal historians to study the outlawry in the 2nd half of the Horthy era and to consider the following questions: Which rhetorical methods were used in the chamber accounts? What was the opinion of the royal notaries ("the wards of the constitutional state") about the violation of equality under the law? Did the outlawry have an impact on the membership in the chamber? If so, how did the royal notaries evaluated these changes? The report of the annual ordinary general meetings began every year with the opening speech of the chamber president, Béla Angyal. Surprisingly Angyal analyzed the political changes instead of professional questions. In 1938 be spoke about the 900th jubilee of the death of King St. Istvan and about the glory of his empire. In 1939 he rejoiced over the annexation of North Hungary (Felvidék) and Subcarpathia, which he called the "resurrection of Hungary" after the tragical peace treaty in Trianon 1920. In 1940 Angyal considered it necessary to celebrate the 20th jubilee of the governor's reign, who was honored as "Savior of Hungary sent by God" and achieved the annexation of East Hungary and a part of Transylvania. The general meeting began this year with a common "prayer". This so-called Magyar Hiszekegy ("I believe in one God, I believe in one mother country, I believe in the eternal godlike verity, I believe in the resurrection of Hungary") was not really a prayer, but more like a kitschy and chauvinist quatrain. In 1941 the main topic of the opening speech was the annexation of South Hungary and the chamber president blessed the "wise governor". In 1942 Angyal mourned for the son of the governor, the "young hero of the nation", who died in plane accident in the eastern front lines. In 1943 Angyal designated Word War II (and unexpressed also the convention of Hungary with the Nari Germany) "a fight against communism for Christianity". In 1944 the Notary Chamber of Pécs did not hold the general meeting, and finally in September 1945 the rhapsody of Angyal broke off. Neither in the opening speeches of the chamber president nor in the chamber reports can we find protest against the harm of the principle of equality before the law. The outlawry, especially the anti-Jewish statutes and orders were no problematic for the members at the general meetings or they simply remained quiet. When the number of the Jewish notaries was limited in the chambers, Angyal suggested the introduction of the notary identity card and in 1945, when he informed the membership that the notary of Mohács, Gyözó Kraus₹, did not return from the extermination camp, he did not use the word "unfortunately".

Keywords: notary chamber, anti-Jewish laws, violation of equality under the law, Hortby era 


\section{A kutatás kérdései és forrásai}

A Pécsi Közjegyzői Kamara iratai fontos kordokumentumok. Különösen a kamara évi rendes közgyűléseinek szószerinti jegyzőkönyvei világítanak rá arra, hogy a köztörténeti illetve politikai eseményekre milyen módon reagáltak a kamara képzett, a korabeli társadalmi elithez tartozó tagjai. Az ún. Horthy-korszak második felének (1838 - 1945) jogkorlátozó illetve jogfosztó intézkedéseivel foglalkozó jogtörténész számára fontos az is, hogy az elnöki nyitó beszédben vagy a kamarai jelentésben milyen retorikai eszközöket használnak, hogy a magukat a jogállamiság biztosítékának tekintő királyi közjegyzők miként vélekedtek a jogegyenlőség sérelméről, hogy a kamara összetételére milyen hatást gyakorolt a jogkorlátozás és ezt hogyan értékelték a kamarai tagok. Az alábbi tanulmányban ezekre a kérdésekre a Magyar Nemzeti Levéltár Baranya Megyei Levéltárában őrzött iratok segítségével keresem a választ.

\section{A kamara évi rendes közgyüléseinek jegyzőkönyvei 2.1. A Szent István emlékév jegyében (1938)}

Pátoszos hangú elnöki köszöntővel kezdődött a kamara Pécsett, 1938. szeptember 8-án tartott rendes közgyúlése, melyen Angyal Béla pécsi, Barna Lajos sásdi, Berz̧senyi Lász̧ló keszthelyi, Csempesz. Dénes letenyei, Csonka Zenó tabi, Debreczeny Deasoő szigetvári, Fehérváry Dęső bajai, Hanny Andor lengyeltóti, Kasza Sándor marcali, Keck László siklósi, Kiss Elemér pécsváradi, Májay Dęsố kaposvári, Mike Imre nagyatádi, Milassin Jenó bajai, Nozdroviczky Ferenc gyönki, Örley György nagykanizsai, Szakáts István szekszárdi, Szilléry Péter pécsi, Szlávi Kornél mohácsi és Várnay Ernő csurgói királyi közjegyzők, továbbá Siklósi Tamás pécsi királyi közjegyző-helyettes vett részt. Angyal Béla kamarai elnök ${ }^{1}$ az igen tisztelt és kedves Kartásakat a Szent István év alkalmából köszöntötte, és az említett tagok jelenlétét a királyi közjegyzők családjában uralkodó otthonos összetartással és együttérzéssel magyarázta. Angyal ebbe a majdhogynem baráti-bajtársi viszonyrendszerbe természetesen azokat is beleértette, akik távolmaradásukat kimentették (Csányi László szekszárdi, Hennyei Lász̧ló igali, Illgenn Aurél dombóvári, Hirmann Gyula bácsalmási, Kenderessy János tamási, Kollár Győző szentlőrinci, Krausz Gyözó mohácsi, Iváncsy István paksi, Mártonffy Bogdán kaposvári, Nemes József bonyhádi, Perger Elemér dunaföldvári és Tarajossy Sándor bácsalmási királyi közjegyzők). ${ }^{2}$

A harmincegy oldalnyi jegyzőkönyvből mintegy hét oldalon ${ }^{3}$ az elnöki nyitóbeszéd található. Ebből másfél oldalon arról olvashatunk, hogy Angyal szerint „milyen messzeható esemény” Szent István király halálának 900 éves jubileumi ünneplése. A jogász kamarai elnök - a közgyúlések szokásos menetéhez képest - aránytalanul hosszú jogtörténeti elemzésbe kezdett: „Ez̧en ünnepségek az egészmüvelt világ elött dokumentálták, hogy bazánk megszentelt terïletén eže éve lakik az államalkotó magyar nemzet. Országalapitó Szent István királyunk müködését számtalan üjságcikek, különbözó elöadások s egyéb munkák kimeritöen méltatták és érdem szerint értékelték. Minket jogászokat különösen azuért érdekel Szuent István müködése mert töle származnake elsö irott jogszabályaink. Az ilyen régi törvényeknek, jogszabályoknak ma már

\footnotetext{
1 Síkabonyi Angyal Béla a neves pécsi büntetőjogász professzor, Angyal Pál bátyja volt. Tíz éven át, 1934 és 1944 között volt a Pécsi Közjegyzői Kamara elnöke.

${ }^{2}$ MNL BML IX.705 340/1938 1.

${ }^{3}$ MNL BML IX.705 340/1938 1-7.
} 
csak történeti jelentöségük van ugyan, de azért nem érdektelen azokról röviden megemlékezni. Szent István < végezményeinek> két könyve ismeretes. Az elsö azokat az erkölcsi, kormányzati <tanácsokat >, <intelmeket> tartalmazza, amelyeket a király fiához intézett. A második részben túlnyomóan egyházi és büntetö rendelkezések. foglaltatnak, de abban némely magánjogi vonatkozású törvények is fellelhetök. Nem lesz talán érdektelen ezeek közüll egyes, mint közjegyzőket különösen érdeklö végezményeket ezúttal felemliteni." Az elnök az istváni dekrétumok tartalmi összefoglalását egy lelkes megjegyzéssel zárta: „Milyen érdekesek ęek az ezeréves ösi magyar jogszabályoke?’. ${ }^{4}$

Beszédének második eleme még kevésbé kapcsolódott a közjegyzői tevékenységhez. Szükségesnek tartotta, hogy megemlékezzen az 1938-ban Budapesten tartott eucharisztikus világkongresszusról, „mely alkalommal sok külföldi fordult meg hazánkban, kik megismerve az itteni hely zetet, talán szintén közrelebb segítenek csonka hazánk feltámadásáboz". ${ }^{5}$

Angyal - a Szent István év jelentőségének hangsúlyozásához képest - igen röviden tért ki az igazságügyi miniszter személyét érintő változásra (Lázár Andort a bársonyszékben Mikecz. Ödön követte, aki eddig ugyanebben a minisztériumban államtitkárként tevékenykedett), majd tájékoztatta a megjelenteket, hogy Glánffy János debreceni királyi közjegyző halála következtében a megüresedett felsőházi tagságra rendes taggá Hanny Tódor kormányfőtanácsost, győri királyi közjegyzőt, póttaggá Fekete Lásそ̨ó kormányfőtanácsost, budapesti királyi közjegyzőt választották meg. ${ }^{6}$

Innentől kezdve az elnöki beszéd egy ideig már valóban a közjegyzői tevékenységhez szorosabban kötődő témákról szólt. Ilyen téma volt egyrészt az egylet 1938. évi vándorgyúlése (Pécs, 1938. június 24. és 25.), melynek fő tárgya a közjegyzői rendtartás reformja volt , másrészt a kodifikált magánjog hiánya. „A gyakorlati életben sokszor érezzük, de a jogbiztonság rovására is van az, hogy nincsen a magyar polgári törvénykönyv kodifikálva s míg egyrészröl a még törvényerövel nem bíró törvénykönyv tervezetére, máskor még Verböcryy bármaskönyvében összefoglalt, vagy az országbirói értekęlet által elrendelt s egyéb régi jogszabályokban lefektetett jogszabályokra történik hivatkozás, pedig sokszor még az is kétséges, hogy valamely régi törvény hatályában van-e. Ez gyakran igen különös helyzeteket teremt. Így történhetett, hogy a budapesti törvényszéé nemrég egy hagyatéki perben az 1840. évi VIII. tcikek-re, tehát egy közzel 100 év elötti, de kifejezetten sebol se hatálytalanitott törvényre hivatkozva azt vizsgálta, hogy az örökhagyó jobbágysorba tartozotte? Tebát az. Úr 1938. évében egy perben az a döntó kérdés, hogy az. illetö jobbágysorban lévoónek tekinthetö-e?"s

A példaként említett gyakorlati nehézségen túl érdekes az is, hogy Angyal miként vélekedett a társadalmi viszonyokhoz történő alkalmazkodásról a jogalkotásban. „Az emberi törvények nem készülnek örök idökere, mert azok nem dogmák, mint a vallási tételek. Már maga a túl konz̧ervativizumus is téves tan a magánjogi és szociális vonatkozású törvényalkotás terén s amikor az események vágtában torlódnak egymásra, az. egész társadalom gyökeres változáson ment át s az életviszonyok annyira megváltoztak, a baladó élet nem érbeti be a jog merev tételeivel, hanem e téren is lüktetó életet követel, $s$ ha valahol, úgy e téren is érvényesül az evolucio, mert a régi, idejétmúlt törvényekhez való merev ragaszkodás, azoknak a megváltozott életviszonyokra való rideg alkalmazása, nem csak méltánytalan és igazságtalan, de könnyen kirobbanásra is vezethet. Összhang kell az élet

\footnotetext{
${ }^{4}$ MNL BML IX.705 340/1938 2-3.

${ }^{5}$ MNL BML IX.705 340/1938 3-4.

${ }^{6}$ MNL BML IX.705 340/1938 4.

${ }^{7}$ MNL BML IX.705 340/1938 5.

${ }^{8}$ MNL BML IX.705 340/1938 6.
} 
és a jog között, mert csak igy születik meg az. igazság és ezzel a társadalmi nyugalom, megelégedés és általános béke."”

Mielőtt az olvasó némán bólintana a fenti mondatokra, szeme továbbsiklik az írott szövegen, és bólintás helyett inkább kérdést fogalmaz meg. Vajon milyen társadalmi változásokra gondolt a kamarai elnök, amikor a jogi változásokat sürgette a társadalmi és gazdasági élet egyensúlyának hatályosabb biztosításáról szóló ún. első zsidótörvény (1938. évi XV. tv.) elfogadásának évében?

Angyal a kodifikált magánjog hiányáról szóló észrevételei után újra letévedt a közjegyzőket érintő témák által kirakott útról, és politikai programbeszédbe illő, világos értékelést adott a jelenlévő királyi közjegyzőknek: „Kedves Kartársaim! Világtörténeti időkben élünk s nagy jelentôségü események játszódnak le körülöttünk, melyek kihatásai beláthatatlanok. Mi, maroknyi magyar nép a nagyhatalmak közepette csakis a csendes szemlélö szerepét tölthetjük be, megvárva a helyzet kialakulását. De egyet tartsunk be: legyünk és maradjunk mindenkor magyarok, ne utánozzunk idegen intézményeket, hanem ragas₹kodjunk ezeréves ösi alkotmányunkhoz és a magyar nemzeti geniusnak megfelelö módon az ösi hagyományok tiszteletben tartásával törekedjünk megoldani az elént torlódó társadalmi problémák.at. (...) Hitem az, hogyha kitartunk a keresztény, magyar nemzeti erkölcsök mellett s nem türjük, hogy ocsmány férgek rágják a magyar haza életfáját, akkor élni és virulni fog a ma még létért küzdös bilincsbe vert drága magyar hazánk. Adja Isten, hogy úgy legyen?’ A jelenlévők az elnöki nyitóbeszédet hangos éljenzéssel fogadták. ${ }^{10}$

Ezek után Májay Desső kaposvári királyi közjegyző, a kamara titkára az éves kamarai jelentést olvasta fel. Ennek első tartalmi eleme a gazdasági helyzet vázolása volt. A mezőgazdasági és ipari termelés nehézségeit valamint a kereskedelmi élet problémáit a jelentés elsősorban az országot 1931 óta sújtó gazdasági válsággal, másodsorban a Darányi-kormány által tervbe vett és az Imrédykormány által megvalósított reformokkal magyarázta, melyek páratlan gyorsasága „a sokekal lassúbb, fokozatos fejlödéshez szokott gazdasági életünkben átmenetileg némi zavart keltettek". Ennek hatásai a közjegyzői kart is sújtották: „ba nem is az ügyek számának minden téren való apadásában, de az ügyek érdemleges voltának csökkenésében és a feleknek abban a természetszerü igyekezetében, hogy a lehetséges többféle megoldások közül mindenkor a legcsekélyebb költséggel járót válassqák, még akekor is, ha a másik - valamivel költségesebb - megoldásnak az elónyösebb voltáról vannak is meggyóródve". ${ }^{11}$ Az elnöki nyitóbeszéd pátoszához igazodott, hogy a jelentés készítői ezek után gyorsan hitet tettek a szebb és jobb jövőről szóló hivatalos kormányzati ígéret mellett: „Rendületlenül bizunk azonban a gazdasági helyzetnek a közel jövóben való eróteljes javulásában". ${ }^{2}$ A kormány iránti határtalan lojalitás fedezhetô fel abban a megállapításban, hogy a szebb és jobb jövőben való bizakodás indokolja az adóterhek növelését, mert ezzel a kormány már valóságnak vette a fellendülést, amit a lakosság még csak remélt.

A jelentés második tartalmi eleme az igazságügyi miniszteri széket és egy államtitkári pozíciót érintő személyi változás volt, ${ }^{13}$ majd harmadikként a friss jogforrásokat (törvények, rendeletek) illetve a javaslatokat sorolták fel. ${ }^{14}$ Mivel a közgyűlési jegyzőkönyvben sem az itt közölt

\footnotetext{
${ }^{9}$ MNL BML IX.705 340/1938 6-7.

${ }^{10}$ MNL BML IX.705 340/1938 7.

11 MNL BML IX.705 340/1938 9.

12 MNL BML IX.705 340/1938 10.

${ }^{13}$ MNL BML IX.705 340/1938 10.

${ }^{14}$ MNL BML IX.705 340/1938 11-12.
} 
lista elôtt, sem utána nem tettek említést a társadalmi és gazdasági élet egyensúlyának biztosításáról szóló 1938. évi XV. törvényről, hanem az elnöki nyitóbeszéd és a jelentés is a politikai változásokkal való elvi egyetértést tanúsította, vélelmezhetô, hogy a kamarai elnök és a jelentés készítôi ezt a törvényt is helyesnek tartották, és nem sértette őket, hogy az újra és újra hivatkozott ezeréves magyar alkotmánynak 1867 illetve 1895 óta a zsidók polgári és politikai valamint az izraelita felekezetek felekezeti jogegyenlősége is része volt. Akit pedig mindez mégis zavart, az - hiszen a királyi közjegyző jogalkalmazó volt, akinek a hatályos pozitív jog szerint kellett eljárnia - inkább csöndben maradt vagy esetleg meg sem jelent. Az aktuálpolitikával mélyen átitatott légkör másra talán nem is adott lehetőséget abban a „magyar és keresztény” hazában, ahol szép számmal éltek a magyarok mellett más népcsoportok és a keresztények mellett nem keresztények is.

Innentől kezdve a közgyűlési jegyzőkönyv szakmai kérdésekkel foglalkozott. A közjegyzői gyakorlat számára releváns felsőbírósági határozatokat ${ }^{15}$ elemezték, az ebben a kamarai évben elhunyt királyi közjegyzőkről emlékeztek meg és a friss kinevezéseket ${ }^{16}$ sorolták fel, majd mindezt az ügyforgalmi és a számviteli jelentés ${ }^{17}$ követte.

A jegyzőkönyv arról tanúskodik, hogy a Pécsi Közjegyzői Kamara 1938. évi rendes közgyűlését átitatta a trianoni békeszerződés utáni éveket jellemző nemzetsirató, de a nemzet feltámadásában bizakodó légkör. A kormányzati tevékenységet feltétlenül támogató politikai megnyilvánulások jellemezték a rendezvényt, amelytôl politikai állásfoglalást nyilvánvalóan senki sem várt el, és amelynek teljes egészében szakmai fórumnak kellett volna lennie. A kamara személyi összetételére nézve csak a nevek hangzása ad némi bizonytalan eligazítást, hiszen a felekezeti és etnikai hovatartozásról vagy a politikai felfogásról listák - helyesen - nem készültek, vagy azok a kamarai iratok között nem maradtak fenn.

\subsection{A Felvidék és Kárpátalja visszacsatolása feletti öröm jegyében (1939)}

A Pécsett 1939. szeptember 8-án tartott rendes közgyúlésen Angyal Béla pécsi, Barna Lajos sásdi, Berzsenyi László keszthelyi, Csempesz Dénes letenyei, Csonka Zenó tabi, Fehérváry Dezső̋ bajai, Hanny Andor lengyeltóti, Hirmann Gyula bácsalmási, Illgen Aurél dombóvári, Iváncsi István paksi, Keck Lásæló siklósi, Kiss Elemér pécsváradi, Májay Dęső́ kaposvári, Mike Imre nagyatádi, Milassin Jenő bajai, Nozdrovičky Ferenc gyönki, Örley György nagykanizsai, Siklósi Tamás bonyhádi, Szilléry Péter pécsi, Szlávi Kornélmohácsi, Tarajossy Sándor bácsalmási és Várnay Ernő csurgói királyi közjegyzők, továbbá Vass Gyula pécsi királyi közjegyző-helyettes vett részt. Távolmaradását Csányi Lász̨ó szekszárdi, Hennyey László igali, Kasza Sándor marcali, Kenderessy János tamási, Kollár Gyözoó szentlőrinci, Krausz Gyỡzó mohácsi, Mártonffy Bogdán kaposvári, Nozdroviçłyy Ferenc gyönki, Perger Elemér dunaföldvári és Szakáts István szekszárdi királyi közjegyző mentette ki.

A kartársak meleg szeretettel történő köszöntésekor Angyal Béla kamarai elnök a kamara tagjai közötti hagyományos együttérzést és barátságot méltatta, melyre „mindenkor, de mostanában

\footnotetext{
15 MNL BML IX.705 340/1938 13-15.

16 MNL BML IX.705 340/1938 16.

17 MNL BML IX.705 340/1938 18-30.
} 
fokozottabb mértékeben szülkség van, hogy igy a közjegyzöi intézménynek azööt egy igaz jogállamban megilletö méltó belyét bižtositsuk, ha kell, kiharcoljuk". ${ }^{18}$

Mivel az elnöki nyitóbeszéd tökéletes képet ad arról, hogy a köztörténeti-politikai változásokat hogyan élte meg a korabeli társadalmi elithez tartozó kis csoport, azaz a Pécsi Közjegyzői Kamara elnöke és valószínűleg a tagjai is, nem felesleges azt hosszabban ismertetni. A fent idézett mondat a következőkkel folytatódik: „Alig pár nappal múlt évi közgyülésünk után megindult a bomlási folyamat a Benes által összehazudott, mesterségesen összetákolt szomszédos Csehszlovákiában. Drámai gyorsasággal követik egymást az események! Két keserves évtized sz̨envedése, kürdelmei s annyi megpróbáltatások után, múlt év szeptemberében végre örömnapok virradtak hazánkra. A Felvidékkel egymásután tértek vissza Szent István országába Komárom, Léva, Losonc, Ungvár, Munkács, Kassa. Az emlékeezetes öszi napokat nyomon követték az életfakasztó tavasæi napok. Március 15-e, a magyar sæabadság napja meghożta Kárpátalja felszabadulását s dicsö honvédeink bámulatos teljesitménye folytán a régi magyar határon üjra ott leng a háromszinü magyar lobogó. A visszacsatolt terïletek berendezése, a magyar impérium helyreállitása tengermyi munkát ad az. illetékes köröknek. Nap mint nap jelennek meg még ma is újabb rendeletek, amelyek a visszacsatolt területek. jogviszonyait minden téren szabályozzák s a gazdaság helyzetét is renderik. A Felvidék visszacsatolása és Kárpátalja bekebelezése minden magyar ember lelkét örömmel tölti el, de örvendetesen érint minket közjegyzöket is,

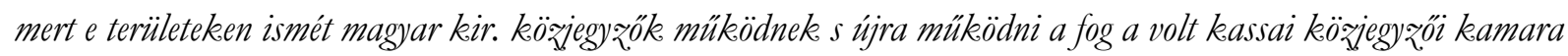
is. Meleg szeretettöl áthatott hazafias kartársi érzéssel köszöntöm a Felvidéken és Kárpátalján müködö kartársainkat s müködésükre Isten böséges áldását kérem?’19

Az elnök Mike István nagyatádi királyi közjegyző kormányzói kitüntetéséről emlékezett meg, a személyi változásokra (Nemes József bonyhádi közjegyző halála és helyére Siklósi Tamás kinevezése) tért ki röviden, majd újra a politikai események következményeivel foglalkozott: „A megcsonkitásunk óta eltelt 20 év alatt országunk egy, az ezeréves nagy múlthoz nem méltó, mondhatnám vegetativ életre kényszerült. Az. ellenünk alakult kis entente államai, mint ellenséges gyürü vettek. körül s igyekeațek, gazdaságilag tönkre tenni, hogy ily könnyü prédaként osztozkodhassanak a magyar földön. Ezuen évtizedek izgalmai, a helyzut bizonytalansága nem volt alkalmas mélyreható reformok megalkotására s a még mindig forrongásban lévó helyzet arra int, hogy várjuk meg a viszonyok végleges tisztulását konszolidálódását s egy olyan nyugalmi állapot elkövetkęését, amely alkalmas lesz. egy végleges, mindenre kiterjedö új közjegyzöi rendtartás megalkotására."20

$\mathrm{Az}$ igazságügyi minisztérium által tervbe vett, a közjegyzői irodákban alkalmazottak jogviszonyaira vonatkozó szabályozás kapcsán Angyal úgy vélte, helyes, ha „a közjegyzói irodákban alkalmazottakról - már csak az.1939. évi IV. tv-re és a 772061/1939 M.E. rendeletre való tekintettel is külön nyilvántartási jegyzéke vezettesséke”. Elhallgatta, hogy a zsidók közéleti és gazdasági térfoglalásának korlátozásáról szóló törvényről és annak végrehajtási rendeletéről van szó, bár ez nyilván minden jelenlévő előtt ismert volt. Tárgyilagosan csupán arra a feladatra koncentrált, amit a pozitív jogi norma elé állított, és mellőzött bármiféle értékelést. ${ }^{21}$

Az elnök ezek után másfél oldalon keresztül az adó- és illetékügyek egységes szabályozására vonatkozó és a kamarának véleményezésre megküldött pénzügyminiszteri rendelettervezetről beszélt, majd - mintegy a fenti hideg távolságtartás indokolásaként - Teleki Pál budapesti, 1939.

\footnotetext{
18 MNL BML IX.705 368/1939 1-2.

${ }^{19}$ MNL BML IX.705 368/1939 2.

${ }^{20}$ MNL BML IX.705 368/1939 3.

${ }^{21}$ MNL BML IX.705 368/1939 4.
} 
szeptember 1-jei beszédét idézte, melyben a miniszterelnök az ország lakosságát arra szólította fel, hogy „általános közérdekböl, valamint minden egyes polgár jól fellfogott egyéni érdekéböl teljes erövel arra törekedjen, hogy a hatóságok hazafias munkáját megkönnyitse. A nyugalom és a rend fenntartása mindannyiunk kötelessége. Midôn ezt kérem, a mai éves rendes közgyülésünket Isten nevében megnyitom”. 22 A tagság pedig lelkesen éljenzett...

Amilyen az elnöki nyitóbeszéd volt, olyanra sikerült a kamara évi jelentése is, amelyet a jegyzőkönyvvezetéssel megbízott királyi közjegyző, Siklósi Tamás olvasott fel. A tizennégy oldalnyi jelentésből több mint egy oldal ismét a köztörténeti-politikai változásokkal foglalkozott. Kulcskifejezései („„zegény, megcsonkitott hazánk”, „agyonsanyargatott nemzet”, „Trianon átka”) jól jellemzik a közhangulatot és a közjegyzői karban is uralkodó atmoszférát: „A magyarság pedig, eza az. egyébként egységre nehezen képes faj, egy emberként mélységes ábitattal és csodát váró lélekkeel fordult valláskülönbség nélkül az. Egek. Uráboz, óvja meg, segitse meg szerencsétlen bazánkat s adja vissza sok vérrel áztatott, ežer éves határainkat' ${ }^{23}$

A jelentés hangsúlyozta, hogy az elmúlt kamarai évben nem sok érdemleges történt, mert „az ország mindenek fölé emelkedö nagy eseményei mellett természetsz̧erüen eltörpül karunknak belsö élete”. A közjegyzői reformtörvény megalkotását nem látták időszerűnek a külpolitikai tekintetben zavaros időkben, sürgették ellenben a jegyzői magánmunkálatok megszüntetését, ami nem csak a kellő jogismeret esetleges hiánya miatt volt fontos a kamara tagjai számára, hanem azért is, mert a jegyzők ezzel elvonták az ügyfeleket a királyi közjegyzők elől és veszélyeztették azok megélhetését. ${ }^{24}$

A jelentés hosszan elemezte a pénzügyi hatóságok negatív viszonyulását a közjegyzői kamara tagjaihoz: „Rendkivül bántó tehát még a gondolata is annak, hogy éppen a pénzü̈gyi hatóságok, akiknek munkáját nagy mértékben elösegitjük, bennünk adórövidítöket, adócsalókat lássanak csak azért, mert nem vagyunk képesek olyan fantasztikus jövedelmeket bevallani, amelyeket a félrevežtett köz̧hangulat nekünk minden ok nélkül tulajdonit." - szólt a jelentés, majd konkrét eseteket említve jellemezték a nehézség súlyos voltát. ${ }^{25}$ Mindezeket a problémákat - a várakozásokkal szemben - a tényleges gazdasági nehézségekből vezette le a jelentés készítője. „A gazdasági életben tulajdonképpen nagymértékü fellendülésnek kellett volna bekövetkeznie a felvidék visszacsatolásával kapcsolatosan. Sajnos azonban a fellendülés csak egészenen rövid ideig tartott s már az év tavaszától kędve, mióta állandó külpolitikai bizonytalanságban élünk, állandóan fokozódó visszaesést tapasztalunk. Ha a gaz̧dasági élet jelenlegi nyomasztó helyzete meg nem szünik, a lehetö legsötétebb kilátásokkal néz̧hetünk a jövő elé."26 Mindezek következményét a királyi közjegyzők elsősorban az ügyforgalom visszaesésében látták.

Ékesszólással és Isten áldását kívánva köszöntötték Tasnádi Nagy András igazságügyi minisztert és Antal István államtitkárt, majd a jogalkotás kérdésére tértek rá. Olyan törvényt, mely a karra vonatkozó lényegbevágó rendelkezést tartalmazna, nem tudtak említeni, ezért csak utaltak arra, hogy a királyi közjegyzők közlönye magas színvonalon nyújt tájékoztatást minden változásról. ${ }^{27}$

\footnotetext{
22 MNL BML IX.705 368/1939 6.

${ }^{23}$ MNL BML IX.705 368/1939 7.

${ }^{24}$ MNL BML IX.705 368/1939 8.

25 MNL BML IX.705 368/1939 9. és 10-11.

${ }^{26}$ MNL BML IX.705 368/1939 11.

${ }^{27}$ MNL BML IX.705 368/1939 12-13.
} 
A jelentés a jogszabályi változások kapcsán megemlítette azt, hogy „az értelmiségi munkanélküliségnek kormánybiztosa feljelentést tett legtöbb kartársunk ellen a bejelentési kötelezettség megszegése miatt. Az. Igazságügyminiszter Úr köz̧benjárására ezek az ellenünk inditott eljárások megszüntek. Itt emlithetjük meg, hogy a II. zsidótörvény 7720/1939 M. E. sæ. végrehajtási utasitása a 42. J-ban kimondja, hogy a bejelentési

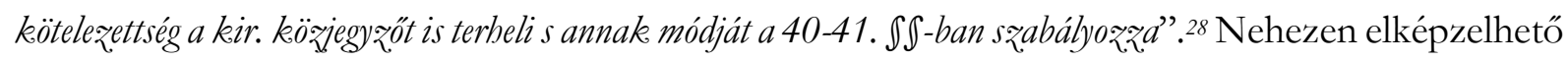
eset, hogy zsidótörvény hatálya alá tartozó munkatárs védelmezése érdekében nem történt meg az előírt bejelentés, és az igazságügyi miniszter mégis gondoskodott az adott közjegyzői iroda elleni eljárás megszüntetéséről. Sokkal inkább életszerűnek tűnik az, hogy az adott királyi közjegyző illetve közjegyzői iroda mulasztása nem volt érdemi, mert az irodában nem volt zsidó munkatárs, és az eljárást ezért szüntették meg miniszteri közbenjárásra.

A királyi közjegyzők számára releváns bírói gyakorlat ismertetését ebben az évben elhagyták. Ehelyett a jelentés azt hangsúlyozta, hogy ez a színvonalas jogi szakfolyóiratokban megtörténik, ezért felesleges. A személyi változásokat tekintve a kamarai évben a bonyhádi királyi közjegyzői állás üresedett meg Nemes József szolnoki áthelyezése miatt. Az állásra Siklósi Tamást nevezték ki. A jelentést az ügyforgalmi mutatóval és annak részletes indokolásával folytatták, míg a jövő év feladatairól nem szóltak. Ennek oka kézenfekvő volt: „Sajnos el kell ismernünk, hogy a mai idó, mely egyik percröl a másikra a legnagyobb meglepetések elé állithatja az egész világot, semmiképp sem alkalmas arra, hogy mi a jövó feladatainak megvalósitását sürgessük és ezen elmélkedjünk. Egyelöre örüljünk, ha rendes napi feladatunkat zavartalanul teljesithetjük és existenciánkat úgy-ahogy biðtositva látjuk."29

A kamarai év számadásának vizsgálása után a közgyűlés a számvizsgáló elnök jelentését tudomásul vette és a pénztárkezelő elnöknek a felmentvényt a szokásos óvás mellett megadta. A kamara újraalakítása mint mindenkor, most is titkos szavazással történt. A Pécsi Királyi Közjegyzői Kamara elnöke - 18 szavazattal a lehetséges 19 szavazatból - továbbra is Angyal Béla maradt. Ennek a választásnak nem csupán a szakmai munka értékelése tekintetében van üzenetértéke, hanem azt is kifejezi, hogy a köztörténeti-politikai események elhangzott értékelésével és az elnöki beszédben megfogalmazott reakciókkal a tagság minden bizonnyal egyetértett. ${ }^{30}$ A jövő évi költségvetés előterjesztése vitát nem váltott ki. Annak elfogadása után Angyal Béla indítványozta, hogy a közjegyzők és a közjegyző-helyettesek részére a kamarai elnök aláirásával és a kamara pecsétjével ellátott fényképes igazolványt állítsanak ki. A határozat a részletes indokolást nem tartalmazta, csak azt mondta ki, hogy ,a közgyülés ežen megokolt indítványt belyesnek tartja”. ${ }^{31}$ Bár a kamarai igazolvány további tartalmi elemeit a határozat nem adta meg, az ún. II. zsidótörvényből következő bejelentési kötelezettség innentől kezdve nem jelenthetett problémát.

A jogállamiság védelmének szépen hangzó jelszava lehetett az oka annak is, hogy Fekete Lász̨ó budapesti királyi közjegyző a Királyi Közjegyzők Közlönye 1939/10. számában precíz tanulmányt publikált $A z$ un. zsidótörvények s az azzal kapcsolatos rendeleteknek a közjjegyzói gyakorlatot érintố magánjogi rendelkęései címmel tízoldalnyi terjedelemben (293-303.). A tanulmány, amely elsősorban a zsidónak minősülő személyek mező- vagy erdőgazdasági ingatlanszerzési képességéről szólt, egy figyelmeztetéssel zárult: a jogállamiság őre kérte kartársait, hogy kétség esetén világosítsák

\footnotetext{
28 MNL BML IX.705 368/1939 13.

${ }^{29}$ MNL BML IX.705 368/1939 20.

30 MNL BML IX.705 368/1939 23.

31 MNL BML IX.705 368/1939 26.
} 
fel a feleket a vázolt súlyos magánjogi (telekkönyv-jogi) jogkövetkezményekrôl. A jogszabály jogállami karakterérôl vagy annak hiányáról nem fogalmazott meg véleményt.

\subsection{A kormányzó országlását ünnepelve (1940)}

Bár a Budapesti Közjegyzői Kamara már 1938-ban Papp-Váry Elemérné Sqiklay Szeréna 1920-ban írt háromsoros nemzeti imájával, a revizionista Magyar Hiszekegy ${ }^{32}$ elmondásával kezdte meg közgyűlését, ezzel a gyakorlattal Pécsett - elnöki felszólításra - először csak az 1940. szeptember 8-i évi rendes közgyűlés jegyzőkönyvét olvasva találkozhatunk. A jegyzőkönyv nem szól arról, hogy a jelenlévő kamarai tagok (Barna Lajos sásdi, Berzsenyi Lász̨ó keszthelyi, Csempesz Dénes letenyei, Hanny Andor lengyeltóti, Illgenn Aurél dombóvári, Iváncsy István paksi, Kiss Elemér pécsváradi, Köszeghy Antal szentlőrinci, Májay Dezsố kaposvári, Mike Imre nagyatádi, Örley György nagykanizsai, Siklósi Tamás bonyhádi, Sqlávi Kornél mohácsi királyi közjegyzők, valamint CsoloszJenō szigetvári és Vass Gyula pécsi királyi közjegyző-helyettesek) Angyal Béla kamarai elnök felszólításának ne engedelmeskedtek volna.

Angyal nyitó beszédében ebben az évben sem fukarkodott a világos politikai üzenettel. „Ez év március hó 1-én egész. Magyarország bensöséges, meleg érzésekekel ünnepelte vitéz nagybányi Horthy Miklós országlásának huszadik évfordulóját. Ha visszatekintünk a trianoni békediktátumot követö idökre, úgy látszik, hogy halálos aléltságba esett hazánkat akkor egy pis₹kos, szennyes áradat boritotta el, melynek qavarosában felbukkeanó ocsmány férgek pusztitották embertelen módon Magyarország életerejét, sæipolyozták vérét! De akadtak. még magyarok, akik szövetkeztek a haza megmentésére. A <szegediek> üzenetet küldtek Kenderesre Horthy Miklós kúriájára is. A felelet röviden eq volt: <Hivtatok, itt vagyok! > És megkęqödött a Magyarországot üjjáépitö nagy küzdelmes munka. Hortby Miklós (...) büséges, magyar munkatársaival megkędte az elesett, szegény, kifosztott magyar hazánk feltámasztását. A helyzuet kétségbeejtö volt. Megcsonkitott hąánkat prédára lesö ellenség vette körül, barátunk sehol! Ekekor, talán Magyarország patrónájának anyai szive könyörült meg bazánkon és eszközöltte ki Istenfiánál, hogy olyan vezetöt adott nemzetünknek, aki kivételes kormányzói képességével, a magyar nemzet jövöjébe vetett töretlen hitével, lehetövé tette, hogy a lelkében megrendült magyar nemz̨et elesettségéböl felemelkedve, az ö vezetésével rálépjen az épitô munka útjára. A régi római birodalom Róma alapitásától - ab urbe condita - számitotta az éveket. Magyarország üjjáépitését joggal vitéz nagybányai Horthy Miklós kormányzóságának kezdetétöl számithatjuk, s ma annak 20-dik évfordulóján adjunk hálát a Gondviselésnek, hogy öt adta nekünk s kérjük, hogy segitse továbbra is szeretett magyar hazánk, Nagymagyarország feltámasztására irányuló áldásos munkájában?’33 A neobarokk giccsekkel díszített és a rekatolizáció szellemét idéző, túlzásoktól hemzsegő dicshimnuszt olvasva egy kérdést mindenképp feltehetünk: nem lehetett volna Magyarország Trianon utáni történelméből a pozitívumokat, eredményeket - melyeket konkrétan egyébként nem is említett - kiegyensúlyozott megközelítéssel értékelni, ha már a kamara jogász elnöke politizálásra adta a fejét? A Bizánc bukása előtti időszak krónikásainak vakságával vetekszik az a köd, ami 1940 szeptemberében még örömmámorral itatta át a kamarai elnököt a józanság lehelete helyett. A hivatalos propagandisták sem énekelhették volna meg szebben Horthy tetteit.

\footnotetext{
32 A Budapesti Közjegyzői Kamara 1938. március 26-i közgyúlési jegyzőkönyvét lásd MNL BML IX.705 187/1938

${ }^{33}$ MNL BML IX.705 sz. n./1940 1-2.
} 
Az elnöki nyitóbeszéd második részében Angyal „biæalommal és reményteljesen” üdvözölte Radocsay László volt főispán kinevezését igazságügyi miniszterré, miután Tasnádi Nagy András volt minisztert a képviselőház elnökévé választották. Angyal biztosította a jelenlévőket Radocsay jóindulatáról, aki a kamarai elnök gratuláló feliratára „meleg hangú levélben” válaszolt. ${ }^{34}$

Angyal röviden szólt a közjegyzői reformtörvény tervezetéről, melyet a Budapesti Közjegyzői Kamara elnöke, Lázár Ferenc készített és terjesztett az igazságügyi miniszter elé. A tervezet egyes részei ellen a leghatározottabban tiltakozott, és közölte, hogy ,feliratában kifejtette a kamara még azt is, hogy az, alaptörvény óta gyökeresen megváltozott viszonyokera és az. újabb jogfejlödésre való tekintettel nem egyes novelláris módositásokra van szülkség, hanem az egész közjegyzöi rendtartás egységes, ujj, korszerü megalkotása volna kivánatos." Tiltakozott a 75 éves közjegyzői korhatár bevezetése ellen ${ }^{35}$, a havi 600 pengő értékben megállapított nyugdíj ellen valamint a kamarai központosítás (azaz az ún. csúcskamara) bevezetése ellen, és kérte az igazságügyi minisztert, hogy a „tervezet tárgyalását, mint idöszrerütlent teljesen mellözzék és helyette alkalmas idöben az egész közjegyzói intézményt magába foglaló törvény megalkotásához, szülkséges lépéseket" tegyék meg.36

Az elnöki nyitóbeszéd - Kollár Gyơ̋ő szentlőrinczi királyi közjegyző haláláról történő megemlékezés után ${ }^{37}$ - egy ismételt politikai értékeléssel zárult: „Most harmadszor világitott be a fénysugár a trianoni sötét éjszakába és az, augusztus 30-i bécsi döntés alapján ez év szeptember 5-én már átléptéke. honvédeink. Erdély határát és 11 -én már bevonulunk kincses Kolozsvár ösi magyar városába és a Székelyföldre. Így ha nem is teljesedik minden vágyunk, mert bisz. még sok magyar honfitársunk van idegen uralom alatt és Erdély is csak részben került vissza, mégis teljes bizalommal nézhetünk a jövő elé azon reményben, hogy idövel az igazság gyỡzni fog és Szent István birodalma újból nagy és erös lesæ". 38 Angyal megállapította, hogy kik azok, akik távolmaradásukat kimentették ${ }^{39}$, majd átadta a szót Májay Desső kamara titkárnak, aki felolvasta a kamara évi jelentését.

A hét oldal terjedelmû jelentés első oldala ismét a politikai eseményekrôl szólt: a „baráti nagy Németország háborújáról’ Lengyelország ellen, „a győzedelmes német hadsereg” sikeréről Franciaországban, majd a német-olasz-magyar müncheni értekezletről, amely az 1940. augusztus 30-i bécsi döntéshez (Erdély egy részének visszacsatolásához) vezetett: „Bármennyire is fáj a sqiviünk. a Romániában maradt testvéreinkért és azért, hogy Erdélyt, mely sziviünkhöz nôtt mindannyionknak, nem kaptuk vissza egész̨en, ebbe bele kell törödnük"” - szólt a következtetés. ${ }^{40}$

A jelentés szerint „az elmúlt kamarai év alatt nem sok emlitésre méltó és karunkat érintö esemény történt”, és ezekről a Közjegyzők Közlönye rendszeresen be is számolt. Radocsay László miniszteri kinevezéséről ${ }^{41}$ itt is nagy örömmel emlékeztek meg, kiemelve a volt föispán (Komárom -

\footnotetext{
${ }^{34}$ MNL BML IX.705 sz. n./1940 3.

35 Angyal Béla 1867-ben született, azaz 1940-ben 73 éves volt.

36 MNL BML IX.705 sz. n./1940 5.

${ }^{37}$ MNL BML IX.705 sz. n./1940 5.

${ }^{38}$ MNL BML IX.705 sz. n./1940 6.

${ }^{39}$ Csányi László szekszárdi, Debreczeny Jenō szigetvári, Fehérváry Dęső bajai, Hennyei Lásæló igali, Hirmann Gyula bácsalmási, Kasza Sándor marcali, Keck László siklósi, Kenderesy János tamási, Krausz Gyóző mohácsi, Mártonffy Bogdán kaposvári, Csonka Zenó tabi, Milassin Jenó bajai, Nędreveczky Ferenc gyönki, Perger Elemér dunaföldvári, Szakáts István szekszárdi, Szilléri Péter pécsi, Tarajossy Sándor bácsalmási és Várnay Ernő csurgói királyi közjegyzők.

${ }^{40}$ MNL BML IX.705 sz. n./1940 7.

${ }^{41}$ Radocsay 1939. november 9-től 1944. március 22-ig volt igazságügyi miniszter.
} 
Esztergom - Győr vármegyék) „egyéniségének kiválóságát”, amely „a legszebb reményekre jogositja fel” a kamara tagjait, és ezekben ,semmi esetre sem fognak csalódni”. Sokat mondó mondatok...

Megtudjuk azt is egy félmondatból, hogy Radocsay 1939. december 12-én „tisztelgett” is a karnál, azt azonban csak vélelmezhetjük, hogy ez a látogatás kapcsolatban állt a másnapi pécsi értekezlettel, amelyet „az ún. ₹sidótörvények gyakorlati alkalmazása tárgyában” tartottak: „Elóadó Siklósi Tamás dr. bonyhádi kartársunk volt, aki részletesen ismertette a törvény és rendelet folytán a szerzốdéseknél és a hagyatéki eljárásnál követendö szabályokat. A jelenlévök hozzászólásai folytán kialakult megállapodásokat a magunk miheztartása végett a kamara kinyomatta s egyöntetü eljárás végett kamaránk tagjainak megküldötte". Az értekezlet célja tehát az volt, hogy a közjegyzői eljárás feltétlenül jogszerű legyen és a gyakorlat egységesen alakuljon. Nem feltétlenül az ellenvélemények megfogalmazásának helye volt, így nem is olvasható a jegyzőkönyvben semmi arról, hogy egyáltalán felmerült volna bármiféle ellenvélemény a formailag hibátlan jogi norma tartalma ellen erkölcsi vagy természetjogi elvekre, esetleg a jogállamiság sérelmére hivatkozva. ${ }^{42}$

A jelentés sérelmezte a közigazgatási szervek gyakori beavatkozását a közjegyzői hatáskörbe, illetve a községi és körjegyzők okiratolási tevékenységét, amely elvonta az ügyfeleket a közjegyzőktől, de nagyra értékelte a társkamarák közötti együttmúködést. ${ }^{43}$ A közjegyzői nyugdíjintézetről szóló rendelet kiegészítése tárgyában készült tervezet kapcsán a jelentés a közjegyzői irodákban dolgozók bizonytalan szociális helyzetét sérelmezte, majd rögzítette, hogy „az un. zsidótörvények végrehajtási rendelete alapján kötelesek a kir. közjegyzök az értelmiségi munkakörben foglalkoztatott alkalmazottaiknak személyében, munkakörében és illetményeiben beállott változásokat félévenkint, január 31-ig és július 31-ig bejelenteni, de ha nem volt változás, ę̧t is külön jelenteni. Felbivjuk kamaránk tagjait, hogy equeket a bejelentéseket pontosan teljesitsék, mert ezáltal sok kellemetlenségtöl mentesülnek." 44 Ezt a rendelkezést azonban nem sérelmezték, csak tudomásul vették.

A jelentés ezek után a közjegyzői novellatervezettel foglalkozott, melyet időszerűtlennek találtak, és a kamarai elnök írásban tiltakozott is ellene az igazságügyi miniszternél. ${ }^{45}$ Végezetül pedig a statisztikai adatok következtek a kamara területén működő királyi közjegyzőkről (változatlanul 32 közjegyző, 16 jelölt, 7 helyettes), továbbá az ügyforgalom alakulásáról, amely összesítésben az 1938. évi 5.432-ről 1939-ben 5.920-ra növekedett, ami a másolatok és fordítások hitelesítésének jelentősen magasabb számából következett, miközben az óvások száma csökkent, a hagyatéki ügyek és a beadványok száma pedig nem számottevő mértékben nőtt. ${ }^{46} \mathrm{~A}$ jelentés szerint a kamara területén 8 királyi közjegyző és 3 helyettes teljesített ekkor már hosszabb idő óta katonai szolgálatot. Bár a közérdekű munkaszolgálat mellett 1940 nyarán a mozgósítási program keretében már felállították az ún. különleges munkásszázadokat a fegyveres szolgálatra alkalmatlannak vagy fölöslegesnek talált zsidó állampolgárokból ${ }^{47}$, a jelentés munkaszolgálatos kamarai tagról nem tett említést.

\footnotetext{
${ }^{42}$ MNL BML IX.705 sz. n./1940 8.

43 MNL BML IX.705 sz. n./1940 9.

44 MNL BML IX.705 sz. n./1940 10.

45 MNL BML IX.705 sz. n./1940 10-11.

${ }^{46}$ MNL BML IX.705 sz. n./1940 12.

${ }^{47}$ SZITA, Munkaszolgálat 16.
} 
A jelentés elfogadása után a jegyzőkönyvben a számadást és a kamarai tisztségviselők következő évre történő választását rögzítették. ${ }^{48}$ Angyal Bélát 17-ből 16 szavazattal ezúttal is újraválasztották kamarai elnökké, ami azt bizonyítja, hogy a jelenlévők és három távolmaradó tag, akik postán küldték be szavazatukat, messzemenően elégedettek voltak a tevékenységével, sőt Mike Imre szükségesnek látta azt is, hogy az újraválasztottat egy teljes jegyzőkönyvi oldalon át, azaz nagyjából 4 percen keresztül éltesse.

A giccses szólamok itt sem hiányoztak: „(...) az emlékezés számyain visszaszállva a múltba megállapitottam, hogy pár nap hiján, pontosan szeptember 12 -én 40 éve lesz. annak, hogy a mi szeretett kamarai

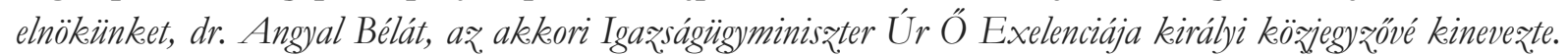
Angyal Bélának bálványai nem voltak, de voltak ideáljai. Ideálja volt a munka, a szorgalom, a felebaráti szeretet, mely ideáljait soba el nem hagyta s az ideálok is hüségesek maradtak öhoz:á. Merem állitani, ha a magyar élet fiatal hajtásai, a magyar ifjúság ezekekel az ideálokkal hagyja el az iskolák padjait, akkor lesz feltámadás, lesz. nagy, boldog és hatalmas Magyarország?' Tagtársai minden bizonnyal egyetértettek Mikével, mert a jegyzőkönyv szerint „a kö̈gyúlés ą elnököt sokáig lelkesen éltette”. ${ }^{99}$ A költségvetés elfogadását követően Angyal az ülést berekesztette. ${ }^{50}$

\subsection{Az országgyarapító bölcs vezér (1941)}

Nem okoz különösebb meglepetést az olvasónak, hogy a Pécsi Közjegyzői Kamara 1941. szeptember 8-i évi rendes közgyúlése - elnöki felszólításra - a Magyar Hiszekegy elmondásával kezdődött, ahogy ez az előző évben is történt. ${ }^{51}$

Az elnök nyitó beszédében köszöntötte azt a 19 közjegyzőt, aki a közgyúlésen „a súlyos idóke" ellenére is megjelentek, felsorolta azokat, akik katonai szolgálatot teljesítettek az év során (Kiss Elemér pécsváradi, Hanny Andor lengyeltóti, Iváncsy Istuán paksi, Csempesz Dénes letenyei közjegyzők) valamint akik még a közgyúlés időpontjában is a szolgálat miatt maradtak távol (Debreczeni Dęső szigetvári és Szakáts István szekszárdi közjegyzők), és megnevezte azokat is, akik távolmaradásukat más okból kimentették (Hennyey Lász̧ó igali, Illgenn Aurél dombóvári, Kasza Sándor marcali, Keck László siklósi, Krausz Győző mohácsi, Mártonffy Bogdán kaposvári, Nozdroviczky Ferenc gyönki, Perger Elemér dunaföldvári, Sz̧illéry Péter pécsi és Tarajossy Sándor bácsalmási közjegyzők).

A mintegy háromoldalnyi nyitó beszéd jelentősége ebben az évben elsősorban abban található, hogy - a már megszokott trinanoni keserűségen és az 1938 óta visszacsatolt területek feletti örömmámoron túl - egyre erőteljesebbé vált a kormányzó dicsőítése úgy, hogy amellé feltétel nélküli engedelmességet is társítottak. „Ez̨en idökre gondolva a hála és kösæönet érzése tölti el mindannyionk lelkét a Fơméltóságú Kormányzó Urunk vitéz nagybányai Horthy Miklóssal szemben (a közgyülés tagjai lelkesen éljeñile a Kormány zó Úr Ôfóméltóságát), akinek a magyar közvélemény joggal adta az <Országgyarapitó> nevet, mert azo ö bölcs, körülttekintö kormányzása juttatta vissza hazánk elszakitott részeit a magyar haza testéhez: Áldja meg a Mindenható Ú risten töretlen erövel, egész̧éggel, hogy még hosszú ideig vez̨ethessen minket a szebb és boldogabb magyar jövö felé. Nekünk, e nemzet napszámosainak pedig szent kötelességünk, hogy a Föméltóságú Kormányzó

\footnotetext{
48 MNL BML IX.705 sz. n./1940 14-16.

${ }^{49}$ MNL BML IX.705 sz. n./1940 17.

${ }^{50}$ MNL BML IX.705 sz. n./1940 20.

51 MNL BML IX.705 346/1941 1.
} 
Úr és Munkatársai mögé tömören és egységesen felsorakozva teljesitsük - ha kell, áldozatok árán is kötelességünket, mert csakis akkor remélhetjük Magyarország teljes feltámadását." "52 Az Angyal beszédéből kitűnő szellem egyrészt kizárta az önálló véleményalkotás lehetőségét, de még inkább annak másokkal történő szabad közlését, másrészt feltűnő módon a kormányzó személyéhez, nem pedig a kormányhoz vagy a miniszterelnökhöz kötődött. Nem túlzó az állítás, hogy a bölcs vezér a korszak emblematikus figurájává lett.

Az ez évi jelentést Májay Dez̧ső olvasta fel. A jelentés az év hadi eseményeivel kezdődött:

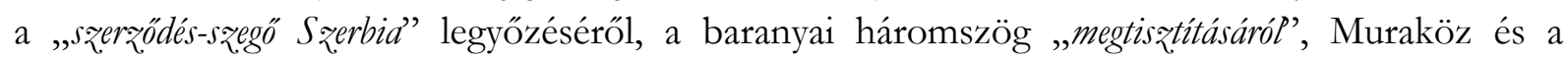
Vendvidék visszatéréséről a „Szent Korona jogara alâ” - szónokolt a kamarai titkár. Majd utalt a területi növekedés következményeire, a régi-új közjegyzőségek (újra)felállítására. A jelentés hangsúlyozta, hogy kevésnek találták az elmúlt évi közgyúlésen a tagok jelenlétét, és nagyobb aktivitást sürgetnek. A közjegyzői rendtartás novellájának újabb tervezetét, melyet a kamara 1941. május 8-án kapott meg, ezúttal üdvözölték. A május 18-i értekezleten a kamarai tagok tárgyalták a tervezetet, majd az észrevételeiket közölték a minisztériummal. Elsősorban azonban hálás köszönetüket fejezték ki „a régóta kivánatos módositásokért, különösen az okiratolás kiterjesztéséért, amely a jogkeresö közönnég érdekeit is élénken érinti, mert nagyon fontos a sok és jó okirat révén a perek megelózése" ${ }^{53} \mathrm{~A}$ novellatervezet a Közjegyzők Közlönye ez év júniusi számában is megjelent, sőt június 7-re a budapesti kamara elnöke kamaraközi értekezletet hívott össze.

Ezen az értekezleten a pécsi kamarai tagok - mivel észrevételeiket a minisztériumnak már megküldték - nem vettek részt, és az értekezlet által kidolgozott tervezetjavaslatot nem is üdvözölték. Az elsődleges problémát a jelentés készítője abban látta, hogy a kamaraközi értekezlet javaslatának 11. \-ában „a magyar közjegyzöi kamarák kö̈ponti közös szerveként a kir. közjegyzói kamarák országos bizottságát [jelölték meg], amit mi idáig csúcskamarának neveztünk, székehelye Budapest és elnöke a budapesti kamara elnöke lenne. E bizottság feladata volna állásfoglalás és javaslat-tétel az igazságszolgáltatásra és jogalkotásra vonatkozó kérdésekben, megfelelö eljárás és állásfoglalás mindazokban az ügyekben, amelyek a kir. közjegyzói kar egyetemét érintik. E szakasz utolsóelötti mondata ažt tartalmazza ugyan, hogy ez a rendelkezés nem csorbitja az egyes közjegyzöi kamarák törvényes autonom batáskörét, de azért lényegében mégis a kamarák felett álló szervezet lenne, ami bizony csökkentené a kamara hatáskörét s ezért kamaránk egy ilyen szervezet megalkotását mindig elleneate." ${ }^{54}$ Ezek szerint a budapesti csúcskamara felállításának terve sértette a pécsi kamara tagjainak érdekét, és ez ellen világosan állást is foglaltak a jelentésben. Jó példa arra, hogy ellenvéleményt kifejteni vagy vitát generálni olyan kérdéseknél mert/akart csak a pécsi kamara, amelyekben a szervezetről és annak hatásköreiről vagy olyan jogi kérdésekről van szó, melyeknek aktuálpolitikai vetülete nem volt.

Ellenben a jelentés röviden említette csak a „rendkivüli idök” következményét, amely „indokolja, hogy a miniszteri rendeletek állandóan nagy számban jelennek meg, melyekkel csak úgy tudunk. megbirkózni, ha indexbe foglaljuk a bennünket érdeklókeet'. E rendeletek tartalmára nézve azonban utalás sem történt: a közjegyzői kar az alakilag jogszerű normákkal szemben nem tett észrevételt. Bár ezek egy része volt csak olyan norma, melyek a közjegyzői tevékenységgel kapcsolatban álltak, mégis meg kell jegyezni azt a tényt, hogy a Szálasi-kormány (1944. október 16. - 1945. március 27.)

\footnotetext{
52 MNL BML IX.705 346/1941 3.

${ }^{53}$ MNL BML IX.705 346/1941 6.

${ }^{54}$ MNL BML IX.705 346/1941 7.
} 
időszakában mindössze 10 ún. zsidórendeletet hoztak, míg az Imrédy-kormány (1938. május 14. 1939. február 16.) 17, a Teleki-kormány (1939. február 16. - 1941. április 3.) 100, a Bárdossy-kormány (1941. április 3. - 1942. március 9.) 72, a Kállay-kormány (1942. március 9. - 1944. március 22.) 78, a Sztójay-kormány (1944. március 22. - 1944. augusztus 29.) 85 és végezetül a Lakatos-kormány (1944. augusztus 29. - 1944. október 16.) 5 ilyen tárgyú rendelettel ${ }^{55}$ büszkélkedhetett, de ennek a kamarai évnek a terméke volt 1941. évi XV. tv. a házassági jogról szóló 1894. évi XXXI. tc. kiegészítésérôl és módosításáról valamint az ezzel kapcsolatban szükséges fajvédelmi rendelkezésekről, továbbá az 1941. évi XIX. tv. is, amely a törvényhatósági bizottsági és a községi képviselőtestületi tagsági jogról rendelkezett.

Az 1941. évi kamarai jelentés egyrészt a jogkorlátozó rendeleti jogalkotás csúcsidőszakában született, amikor a polgári korszak egyik kiemelt jelentőségú jogszabályának, a szekularizált házassági jogot bevezető törvénycikknek a módosítása is megtörtént a házassági akadályok újraszabályozásával a fajvédelem jegyében, másrészt ezeknek az éveknek a jogalkotása előkészítette a teljes jogfosztást, ezért jelentőségük súlya nem vonható kétségbe. Mindezt egy félmondattal a „rendkiviuli idók következményének”” nevezni nagyfokú látászavart tükröz.

A jelentés mindenesetre rögzítette, hogy a kamara kapcsolata a királyi bíróságokkal és társhatóságokkal ebben az évben zavartalan volt. ${ }^{56}$ A kamara területén 36 közjegyző, 14 jelölt (közülük 12 helyettes), 49 segéd múködött, az ügyszám pedig az előző évi adatokhoz hasonlóan alakult, azaz tetemes visszaesés volt tapasztalható. Ennek természetesen van egy olyan üzenete is, hogy a közjegyzők megélhetése jelentős mértékben megnehezedett 1941-re.

A jelentés elfogadása után a jegyzőkönyv a kamara pénzügyi számadásáról, majd a tisztújításról számolt be. A következő évre újra Angyal Béla került a kamara elnöki székébe, akire a leadott 19 szavazatból 18-an voksoltak. ${ }^{57}$ Mike Imre korelnöknek az újraválasztott elnökhöz intézett köszöntése ebben az évben némileg rövidebbre, de stílusában épp oly emelkedettre sikeredett: a szeretettől, „a lélek legértékesebb tulajdonságáról’ szónokolt, melyből „sokat adtunk ma Méltóságodnak azáltal, hogy a mai közgyülés üjra Kamaránk elnökévé választotta Méltóságodat. Adjon a jó Isten Méltóságodnak eröt, egészséget abhoz, hogy ugyanazzal a hozzaértéssel, ugyanazzal a lendülettel és ugyanazzal a kitartással vezesse kamaránkat, mint ahogy ąt eddig tette." ${ }_{58}$ Ezek a mondatok és a tagság lelkes éljenzése azt jelzik, hogy a (jelenlévő) tagok továbbra is elégedettek voltak a dolgok folyásával, az adott körülmények között.

\subsection{Horthy Istvánt gyászolva (1942)}

1942. szeptember 8-ra, a következő közgyúlés idejére a háborús események teljes mértékben a háttérbe szorították a közjegyzőket érintő szakmai kérdések jelentőségét. A közgyưlésen meglepő módon nagy számban vettek részt a kamarai tagok. Mivel a névsorban több változás is felfedezhető nem felesleges a jelenlévőkről pontosan megemlékezni: Angyal Béla pécsi, vitéz. Barna Lajos sásdi, Beræsenyi László keszthelyi, Bertin József csáktornyai, Csempesz Dénes letenyei, Fehérváry Dezső bajai, Debreczeny Dęsō szigetvári, Hirmann Gyula bácsalmási, Illgenn Aurél dombóvári, Jelen Miklós pécsi,

\footnotetext{
${ }^{55}$ KARSAI, A magyarországi zsidótörvények- és rendeletek 144.

${ }^{56}$ MNL BML IX.705 346/19419.

${ }^{57}$ MNL BML IX.705 346/1941 15.

${ }^{58}$ MNL BML IX.705 346/1941 16.
} 
Keck László siklósi, Kiss Elemér pécsváradi, Kováts Kálmán pécsi, Köszeghy Antal szentlőrinci, Májay Dezső kaposvári, Medvegy György lengyeltóti, Mike Imre nagyatádi, Milassin Jenő bajai, Örley György nagykanizsai, Róth Sándor dárdai, Sebestyén Mátyás perlaki, Siklósi Tamás bonyhádi, Szlávi Kornél mohácsi, Vámay Ernō csurgói közjegyzôk valamint Szkladányi László mohácsi és Várnay László csurgói közjegyző helyettesek.

A rendezvény ebben az évben is a Magyar Hiszekegy elmondásával kezdődött, majd Angyal Béla elnök megkezdte szokásos nyitóbeszédét. „1942. február bó 19-én az Országház kupolacsarnokában vitéz, nagybányai Hortby Istvánt, szeretett Kormányzó urunk fiát egyhangú lelkesedéssel az országgyülés kormányzóhelyettesnek megválasztotta sö az ösi Horthy nemzetségnek a férfikora delén levös a legszebb reményekre jogositó tagja, érces hangon mondta el eskiüjét, mondván: <Mindent megteszeke, amit az ország javára és dicsöségére megtehetek>. Ö, a kötelességteljesités mintaképe ezt minden téren teljesitette is és pedig nem csak mint kormányzóhelyettes végezte teljes odaadással teendöit, hanem öseihez. méltóan mint magyar ember és mint katona is ki akarta venni részét a haza védelmében s bár maga közjogi méltóságban nem lett volna kötelessége, úgy érezte, hogy neki, a kormányzóhelyettesnek, a barctéren is elsö sorban kell állnia. Mint kiváló repüló, önként jelentkezett a harctéri szolgálatra és ott érte a minden magyart mélyen sújtó csapás, a bösi halál. Szent István ünnepén quigott végig az országon a szomorú bir, mely gyász̧ba boritotta hazánkat. Vitéz nagybányai Hortby István katonai szolgálata köz̧en az orosz fronton bösi balált halt. 1942. angusztus 27-én ismét ott volt az országgyülés az. országház. gyász̧ba borult kupolacsarnokában, ahol döbbenetes csendben egy fájdalomtól sújtott nemzet várta a

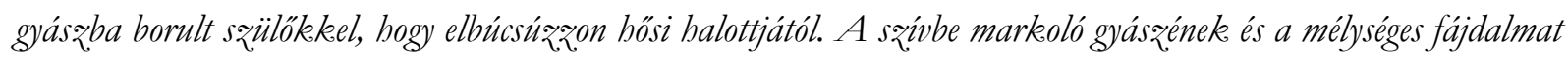
és a nagy veszteséget tolmácsoló búcsúszavak mellett kisérte a nemzet nagy halottját utolsó útjára. Földi maradványait a szeretett haza szent földje fogadta magába s emlékét minden magyar ember szivébe zárta. Az. ezeréves Magyarország történelmének márványlapján a sok dicsö hösünk neve mellett immár ott ragyog az ö neve is. Szolgáljon ezen nagy áldozat sokat szenvedett szeretett hazánk felvirágzására s országunk szebb, boldogabb jövójének megalapozására." ${ }_{59} \mathrm{Az}$ idézett szöveg szóhasználata és fogalmazásmódja többet mond mint bármiféle értékelés; hadd lássa és értelmezze azt maga a 21. századi olvasó, hadd érezze meg azt a légkört, amelyben Hortby fia közjogi méltóságot nyerhetett, és amelyben a nemzet hősi halottjaként a Pécsi Közjegyzői Kamara 1942. évi közgyúlésének is központi szereplője lehetett.

Az elnöki beszéd ezek után a háború eseményeinek felsorolásával folytatódott. Angyal szerint az előző évi közgyủlés idején „talán némi remény mutatkozott arra, hogy a báború förgetege elvonul hazánk felett s mentek maradunk a vele járó szenvedésektöl és nélk.ülönözések.töl. Most belesodrodtunk a csaknem egész világon dúló totális háborúba és nekünk is fegyvert kellett ragadnunk, hogy a barbár keleti veszedelem ellen megvédjük határainkat s biz̧tositsuk hazánk, jövő fennállását. Hála illeti a németek nagy vezérét, hogy bölcs elörelátással megelözte azt, hogy a báború pusztitó réme hazánkat közvetlenül fenyegesse és ezzel vitéz honvédeink az ösi haza földjén, messze a Kárpátokon túl védhetik dicsó haditetteikekel s vérük feláldozásával mai bazánk határait, nemzeti létünket, de ezzel egész. Európa kultúráját is" ${ }^{60}$

Nos, Adolf Hitlert a „németek nagy vezérének” nevezni akkor, amikor a német hadvezetés 1941 telén Moszkvánál súlyos és csúfos vereséget szenvedett, erős túlzás. Ennek következtében $1942-$ től a szövetséges Magyarországtól (pontosabban a több mint 200 ezer fős 2. magyar hadseregtől, amely a harci feladat nagyságához képest rosszul felszerelt és váltást nélkülöző

\footnotetext{
${ }^{59}$ MNL BML IX.705 472/1942 2.

${ }^{60}$ MNL BML IX.705 472/1942 3.
} 
könnyúhadosztályokból állt) erőn felüli teljesítményt vártak el. 1942 júliusának végére már mindhárom magyar hadtest megérkezett a Don folyó vidékére, ahol a következő év áprilisáig harcoltak. Az év végéig 33.763 magyar katona esett itt el ${ }^{61}$, és itt szenvedett halálos repülőgépbalesetet augusztus 20-án Horthy István is. Bár ezekkel az adatokkal Angyal a közgyúlés idején még nem lehetett tisztában, hálásnak lenni Hitlernek azért, mert a 2. magyar hadsereg a honfoglalás kora elôtti magyar területeken harcolhatott, nyilvánvaló vakságra utal. Kérdéses az is, hogy milyen „kultúra” jellemezte azt az Európát (és benne Magyarországot), amelyben a jogállamiság kifejezés 1942-re már csak alaki értelemben volt használható.

Angyal lojalitása a kormányzó és rendszer felé kérdésen felül áll. Az itthon maradókat hosszan buzdította, hogy - miként a frontkatonák - ők is minden áldozatot hozzanak meg a háború sikeres befejezése érdekében, a közjegyzők feladatát is megfogalmazta: „a nagy feladat érdekében belátással, türelemmel kell elviselnünk, sö́t nekünk, akik a nép között élünk s velük közvetlenül érintkęünk, ki kell vennünk a részünket a zon felvilágositó munkából is, mely a belsö rend és fegyelem fenntartására irányul, nehogy az alattomos, gyalázatos bujtogatók aknamunkája egy üjabb kommunista forradalom lángjával végveszedelembe dönthesse országunkat". ${ }^{2}$

S hogy milyen eredményeket várt Angya? A közjegyzői rendtartás reformját (az előző évekkel szemben) most már kívánatosnak tartotta volna, és meg is indokolta ezt: „Ugyanis ha ą̧ akarjuk, hogy a báború befejezése után haz̧ánk az újjá rendezendö Európában elfoglalhassa a Duna-medencében ôt történelmi elhivatottságánál fogva megilletó helyet, akkor már most meg kell tennünk mindent arra nézve, hogy az ország belsö berendezésében minden vonalon teljesen felkészüilve várja a bekövetkezendö eseményeket”. ${ }^{63}$

Angyal bizalma töretlen volt, köszönhetően „kormányunk elörelátó politikájának és a szociális ügyek tekintetében tett intézkedéseknek. Elismerés illeti, hogy gazdaság terén is (...) jelentékenyen bozzájárult országunk várható anyagi megerösödéséhez". Angyal ehhez hasonlóan sürgette a jogi reformokat is. „Nézetem szerint azonban ugyanez̧t meg kell tenni a jogélet terén is, és elö kell készíteni egy modern jogállam intézményeit arra, hogy majdan mutatkozó kívánalmaknak, szülkségleteknek meg is feleljenek. A közjegyzöi intézmény egyike erös pillére a modern jogállamnak (...)". ${ }^{64}$ Mindebből az is világos, hogy a kamarai elnök nem látott problémát 1942 szeptemberében a magyar jogállamiságban; annak fejlesztését azért sürgette, hogy a visszacsatolt területeket az anyaország vérkeringésébe integrálni lehessen.

Hogy a kamarai tagok fejében e mondatokat hallva milyen gondolatok futottak át, nem tudjuk. Azt azonban igen, hogy a kamarai jelentés épp olyan szellemben íródott, mint az elnöki nyitóbeszéd. A „világháború gigászi kürqdelmérö̂p szólt, a szövetséges oldalán „a bolsevižmus elleni keresżtes hadjáratróp’, a „töretlen büségröl és kitartásról’, amellyel Magyarország a „nagy szövetséges oldalán” áll Európa megszerzéséért vívott harcában. A jelentés írója hitet tett a győzelem mellett, amelyet mintegy reformkori szóhasználattal - a „magyarok Istene” fog megadni, aki „,hazánk földjét megkímélte attól, hogy a földi erók hadszintérévé váljék”." ${ }^{5}$ „Európa üjrarendezését" vizionálta a jelentésíró, melyben szerinte „csak a nagy, erös, integer Magyarország lesz képes megvalósitani” a rá váró nagy feladatokat. ${ }^{66}$

\footnotetext{
${ }^{61}$ Az adatokat lásd https://www.masodikvh.hu/hadszinterek/europa/kelet-europa/47-don-kanyar-1942-43

${ }^{62}$ MNL BML IX.705 472/1942 4.

${ }^{63}$ MNL BML IX.705 472/1942 5.

${ }^{64}$ MNL BML IX.705 472/1942 6.

${ }^{65}$ MNL BML IX.705 472/1942 7.

${ }^{66}$ MNL BML IX.705 472/1942 8.
} 
Köszöntötték Angyal Bélát, aki póttagként a felsőház tagja lett, mivel Pécs szabad királyi város felsőházi tagja elhunyt, és megemlékeztek arról, hogy Örley György, vitéz Barna Lajos és Szakáts István közjegyzők a kormányzótól Nemzetvédelmi Keresztben részesültek. ${ }^{67}$ Felsorolták a személyi változásokat a kamarában, és hosszan ecsetelték, miért helytelen az a gyakorlat, hogy nem a pécsi kamarai tagok közül neveznek ki új közjegyzőket a megüresedett helyekre, ahogy ez ebben az évben kivétel nélkül történt. Mivel a jelentés hangsúlyozza, hogy fontos lenne a minimális tapasztalat követelményét érvényesíteni, ezért vélelmezhető, hogy az igazságügyi miniszter a közjegyzői kinevezéséknél nem a tapasztalatot, hanem más szempontokat (lojalitás, megbízhatóság) tartott szem elōtt. ${ }^{68}$

A jelentés megjegyzi, hogy ebben az évben is több kamarai tag teljesített katonai szolgálatot, míg munkaszolgálatra történt behívásról nem tesz említést. Kétségbeejtőnek nevezi, hogy a közjegyzők nem kapnak felmentést a katonai szolgálat alól, aminek súlyos következményét (helyettesítés hiánya, iroda bezárása) a jogkereső állampolgárok fogják megérezni, de maga a kincstár is hátrányos helyzetbe kerül. ${ }^{69}$

A jelentés beszámolt röviden az új törvényekről és rendeletekről is, de egyik esetben sem tett említést arról, hogy ezek bármiféle módon különbséget tettek volna az állampolgárok között vagy jogkorlátozó jellegűek lettek volna. Éppen ellenkezőleg. A hadfelszerelési adó bevezetése (5290/1941. M. E. rendelet) kapcsán megjegyezte a következőt: „Mi az állam bevételeinek fokozását egyrészt az adózás arányositásától, másrészt pedig a nagy vagyonok és a mamut-jövedelmek progressæív megadóztatásától várjuk. Meggondolandónak tartjuk azt is, ne vétessék-e egészen kivételes adózás alá a ssidók vagyona, jövedelme és keresete. A ssidók a honvédelmi törvény novellája folytán ezentúl legfeljebb munkájukkeal, de nem vérülkel szolgálják a hazát, melynek jóvoltából pedig még mindig eléggé jelentös ü̃leti tevékenységet fejtenek ki és ez által éppenséggel nem megvetendö nyereséghez, söt hadinyereséghez juthatnak a hadbavonultakkal szemben. Méltányos és igazságos tehát, hogy legalább a közterbek viseléséböl vegyék ki fokozottabban a részü̈ket". ${ }^{70}$

A jelentés ezek után az igazságügyi miniszterhez intézett kamarai felterjesztéseket sorolta a közjegyzői állandó dijak felemeléséről, a telekkönyvi szabályok egységes szerkezetbe foglalásáról valamint a harmadik pécsi királyi közjegyzői állás megszüntetése elleni tiltakozásról, majd megállapította, hogy „, k kamara sajnálattal tapasztalja, hogy a még oly indokolt felterjesztéseire sem kap semmi választ $s$ azokat a legföbb felügyeleti Hatóságunk úgyszólván sohasem méltatja figyelemre". ${ }^{71}$ A kamarának a bíróságokkal és egyéb hatóságokkal jó volt a kapcsolata ebben az évben is, ellenben Baranya vármegye árvaszékével az év során egy árvaszékelnöki utasítás következtében kialakult (a kamara álláspontja szerint törvénysértő) gyakorlat miatt folyamatos problémája volt.72

A jegyzőkönyvből megtudjuk, hogy a kamara területén lévő „királyi körjegyzői irodák megvizsgálása rész̧ben már foganatosittatott. Az ügykęzelés tekintetében kifogás nem merült feP’. Az irodai alkalmazottakról, az irodák személyi összetételéről nincs említés. ${ }^{73}$ Az éves ügyszámokban jelentős változás mutatkozott 1940 (4.988) és 1941 (5.884) között. Ez az emelkedés (+896) azonban

\footnotetext{
${ }^{67}$ MNL BML IX.705 472/1942 8.

68 MNL BML IX.705 472/1942 9-10.

${ }^{69}$ MNL BML IX.705 472/1942 11-12.

70 MNL BML IX.705 472/1942 14.

${ }^{71}$ MNL BML IX.705 472/1942 16-18.

${ }^{72}$ MNL BML IX.705 472/1942 18-20.

${ }^{73}$ MNL BML IX.705 472/1942 21.
} 
majdnem 50\%-ban az aláírás-hitelesítések számának növekedéséből következett, és a közjegyzők számára magasabb bevételt összességében nem eredményezett; csupán az ügyek megoszlása volt más, mint korábban. A váltóügyek óvása majdnem felére csökkent (1.632-ről 727-re), a hagyatéki ügyek fogyását a jelentés azzal magyarázta, hogy a községi jegyzők továbbra is, szisztematikusan elvonják az ügyfeleket a közjegyzőktől azzal, hogy „a mindig kétes érvényü végrendeletek helyett rendszerint már a halál árnyékában - vagyonátruházási szerzódést állitanak. ki. Ha ez a halálos ágyon való vagyonátadás még soká divik, akkor egy-két évtized múlva nem is lesz bagyatéki eljárásra szü̈kség" - kesergett a jelentésíró. Végezetül a másolatok hitelesítésének csökkenését (5.773-ról 5.394-re) azzal magyarázta, hogy „a zsidótörvény végrehajtása befejezéséhez köz̨eledik”. ${ }^{74}$ Ennek a rövid félmondatnak a jelentősége abban áll, hogy a korábbi jegyzőkönyvekben, amikor a másolatok hitelesítésének megsokasodásáról tettek említést, nem füzték hozzá, hogy az ok az ún. zsidótörvények végrehajtásában keresendő.

A jelentés hangsúlyozta a Közjegyzők Közlönye jelentőségét, mely nélkül a hatalmas mennyiségű új joganyagban és a joggyakorlatban jóval nagyobb erőfeszítéssel igazodtak volna csak el a közjegyzők, majd a következő mondattal zárult: „Vajha adná a Mindenható, hogy a jövő közgyülésünket már a mindannyiunk által oly bön óbajtott és várt béke korában tarthassuk meg és ünnepelhessük örömben mindnyájunk vágyát: a szebb, boldogabb, erôs Nagymagyarországot’.75 A pénzügyi számadás, a tisztújítás (Angyal sokadik, 24-ből 23 szavazattal történt elnöki újraválasztása) és a jövő évi költségvetés elfogadása után a közgyúlést az elnök berekesztette. ${ }^{76}$

\subsection{A kijózanodás ideje? (1943)}

„A szebb, boldogabb, erös Nagymagyarországot” - az 1942. évi közgyűlési jelentés zárószavainak reménységével szemben - azonban 1943. szeptember 8-án sem ünnepelhették. A kamara közgyűlésén megjelent 23 tag (Angyal Béla pécsi, vitéz. Barna Lajos sásdi, Bertin Józssef csáktornyai, Berzsenyi Lász̨ó keszthelyi, Csaplár Vilmos nagykanizsai, Debreczeny Deaső szigetvári, Fehérváry Dęső bajai, Halasy-Rektorisz Lajos gyönki, Illgenn Aurél dombóvári, Iváncsy István paksi, Jelen Miklós pécsi, Kiss Elemér pécsváradi, Köszeghy Antal szentlőrinci, Májay Dezső kaposvári, Mike Imre nagyatádi, Milassin Jenó bajai, Róth Sándor dárdai, Siklósi Tamás bonyhádi, Szakáts István szekszárdi, Sziráky László pécsi, Szlávi Kornél mohácsi, Vargha Pál siklósi és Várnay Ernő csurgói közjegyzők valamint Csolosz. Jenő nagykanizsai, Szkladányi Lász̧ló mohácsi, Vass Gyula pécsi és Várnay Lász̧ló csurgói közjegyző-helyettesek a rendezvényt idén is a Magyar Hiszekegy elmondásával kezdték. ${ }^{77}$

Ebben az évben az elnöki nyitóbeszédből kimaradt a visszaszerzett területek feletti eufórikus öröm, a kormányzót vagy a „németek nagy vezérét” méltató mondatok, de a keleti fronton, az „ősmagyar földön” vívott háború nagyszerüségének naiv igazolása is. Angyal most valóban a kamarát érintő kérdésekre koncentrált. Felsorolta a kamarai évben történt személyi változásokat: áthelyezések (Nozdroviçky Ferenc), lemondás a közjegyzői állásról (Mártonffy Bogdán), természetes

\footnotetext{
74 MNL BML IX.705 472/1942 22.

75 MNL BML IX.705 472/1942 23.

${ }^{76}$ MNL BML IX.705 472/1942 24-29. A közgyűléstől távolmaradtak nevét ebben az évben nem sorolták fel, így nem tudni, hány közjegyző volt frontszolgálaton vagy munkaszolgálaton.

${ }^{77}$ MNL BML IX.705 sz. n./1943 1.
} 
halál (Keck László, Örley György, Kováts Kálmán, Kasza Sándor, Hirmann Gyula) és új kinevezések, de egy szó sem a katonai szolgálatról vagy a munkaszolgálatról.78

Angyal ezek után a közjegyzői intézmény jelentőségéről beszélt öt oldalon (azaz legalább negyed órán) keresztül. Figyelemre méltó mondat beszédében, hogy a királyi közjegyzőkről szóló 1874. évi XXXV. tc. hatályba lépése óta állandó hatásköri problémák kísérték a közjegyzők múködését, aminek ,fó, mondhatni egyedüli oka a politika” volt: „a közjjegyzöség fennállása óta nem tudta magának nálunk kivínni az̧on pozíciót, amely egy igazi jogállamban megilletné, mert az̧ a politikától függetleniteni sobasem sikerült’' ${ }^{79}$ Ennek a politikai befolyásnak több negatív következményét megemlítette.

„Kiküszöbölendönek. tart(otta) a magyar jogéletnek ąt a rákfenéjét, hogy az okiratok. felvételét ma is még a községi jegyzök (...), kello" képzettség nélküli egyének intézile a legnagyobb részben”. Súlyos hibának tekintette a kinevezési gyakorlatot, melyet az igazságügyi miniszterek a pályázatok értékelésekor tanúsítottak, és sürgette, hogy „körjjegyzôvé csak az legyen kinevezhetö, aki az elméleti és gyakorlati

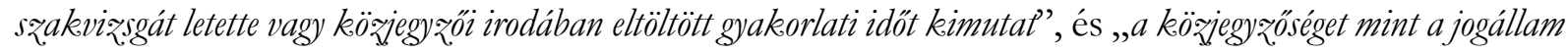

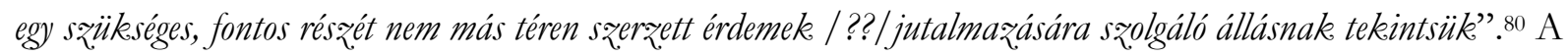
gondolat folytatása is sokatmondó: „Tény az, hogy a tömeges ügyvédi kinevezések miatt a fiatal jogász. nemzedék nem kivánkozile a közjegyzö-helyettesi pályára, látván, hogy másutt szerzett, különösen politikai érdemei jutalmául, összeköttetései révén hamarabb juthat közjegy rói álláshož”. ${ }^{81}$

Az elnöki nyitóbeszédet Angyal azzal fejezte be, hogy ő, mint „a magyar közjegyzőségneke ideális rajongója nyíltan leplezetlenül akar(ta) ezen intézmény érdekében a való helyzetet feltárni. Nekem e téren már nincsen veszteni valóm, mert bizom a törvény erejében, hogy további jogfosztásnak nem leszek, mert nem lebetek. kitéve akekor sem, ha a rideg valóságot nyiltan kimondom". ${ }^{2}$ Az idős elnök itt persze nem az ország közállapotáról beszélt, amikor a jogfosztás kifejezést használta, hanem csupán a közjegyzői intézményről. Mégis kézzel fogható az a fojtogató légkör, amely a politikai vezetésnek történő, kérdések nélküli engedelmesség elvárásából fakadt. A korábbi években Angyal még lelkesen tett eleget ennek az elvárásnak, és a nem közjegyzőket érintő jogfosztás ellen nem emelte fel a hangját még olyan módon sem, ahogy most - erôtlenül - próbálkozott.

A kamara évi jelentését Sikelósi Tamás olvasta fel. Ennek bevezetőjét - a hangnemváltás érzékeltetése céljából - érdemes röviden idézni. „Midön már az ötödik háborús közgyülésünket tartjuk, megrendült lélekekel kell megállapitanunk, hogy a világháború szinte óráról-órára mindinkább általános öldökléssé fajul és bellum omnium contra omnes állapotává válik, amely nem kiméli a békeés polgári lakosságot sem, s aggokat, asszonyokat és ártatlan gyermekeket pusztit el és az emberiség kulturkincseinek a javát teszi a földdel egyenlövé. Olyan a belyzet, mintha az egész. emberiséget valami téboly szállta volna meg, amely a rombolásban és pusztitásban keresi a maga perverz,gyönyörét. Az ember valósággal megcsúfolja magában az. Isten képmására teremtett lényt”'.83 A kormányzó iránti bizalom azonban továbbra is töretlen volt: „Hogy a jövöben mi vár ránk, csak a Mindenható Isten tudhatja, akinek. oltalmába ajánljuk szegény, megpróbáltatások elé nézó hazánkat, s akinek. nem gyözünk eléggé hálát adni azért, hogy 75. életévét éppen legutóbb ünneplö Kormányzó Urunk fennkölt

\footnotetext{
78 MNL BML IX.705 sz. n./1943 3-4.

${ }^{79}$ MNL BML IX.705 sz. n./1943 5.

${ }^{80}$ MNL BML IX.705 sz. n./1943 7.

${ }^{81}$ MNL BML IX.705 sz. n./1943 7.

82 MNL BML IX.705 sz. n./1943 8.

${ }^{83}$ MNL BML IX.705 sz. n./1943 9.
} 
személyében a nemzetnek olyan vezetôt adott, aki bölcsességével, vitézségével és még az ellenséges államok elött is általánosan elismert lelki nagyságával és tekintélyével nemzetünk hajóját még a legháborgóbb vizẹeen át is, hisszük, bogy biztos révbe fogja vežetni". ${ }^{84}$

A jelentésből megtudjuk, hogy több kamarai tag teljesített ebben az évben is katonai szolgálatot. Név szerint Sqakáts Istvánt és Iváncsy Istvánt említették; az elsőt megoldott helyettesítése, a másodikat hadbírói őrnagyként teljesített szolgálata okán, mivel a Királyi Pécsi Honvédtörvényszék vezetője hivatalosan méltatta „értékes katonai müködését’'. Munkaszolgálatos kamarai tagról nem tettek említést. 85

Az új jogszabályok kapcsán a jelentésben megjegyezték a következőt: „Csupán arra óhajtunk rámutatni, hogy a zsidótörvény végrehajtása tárgyában kiadott többrendbeli rendeletek folytán immár annyiféle nyilatkozatnake az okiratba foglalása vált sqülkségessé, hogy ez. már szinte túlzásnak látszik. Úgy véljük, untig elég volna olyan nyilatkozatnak az. okiratba foglalását elöírni, hogy a szerzoódố felek rendelkezési képességét az ún. zsidótörvények és rendeletek semmiképp sem korlátoz:ák"”. ${ }^{86}$ Jogtechnikai megjegyzésrőll volt tehát szó, semmi egyébről.

Sajnálattal állapították meg, hogy az igazságügyi miniszterhez az előző évben intézett felterjesztések eredménytelenek, sőt többnyire válasz nélküliek maradtak. ${ }^{87}$ Újra tiltakoztak többek között a közjegyzői kinevezési gyakorlat ellen ${ }^{88}$ és az új illetékrendelet ellen ${ }^{89}$, majd a Közjegyzők Közlönye ez évi eredményeiről és szakmai jelentőségéről tettek említést, illetve a pénzügyi hatóságoknak a közjegyzőkkel szembeni inkorrekt eljárását panaszolták ${ }^{90}$. A közjegyzői irodák folyamatban lévő felülvizsgálata során szabálytalanságot csak egy hivatalban észleltek, melynek közjegyzője meghalt és helyettesítése nem volt megoldott. ${ }^{91}$ Másról nem tettek említést, aminek az a közvetett jelentése, hogy a közjegyzői irodákban foglalkoztatott személyekről a kötelező jelentéséket rendben megtették a kamara területén. A királyi közjegyzők felsőházi tagjává 1942. december 19-én az igazságügyi minisztériumban tartott gyúlésen a kamarai elektorok Hanny Tódor győri, póttaggá vitéz Fekete Láşló budapesti közjegyzôt választották. ${ }^{92}$ Az ügyszámok alakulását tekintve a háborúval magyarázták a hagyatéki ügyek csekély emelkedését, míg más területen stagnálás mutatkozott. 1941-hez (5.884) képest 1942-ben (6.257) összesen 373-al nőtt az ügyek száma. ${ }^{93}$ Az éves számadás, tisztújítás (azaz Angyal Béla 1934 óta kilencedik, egyhangú elnöki újraválasztása) valamint a következő évi költségvetés elfogadása után az elnök a közgyúlést berekesztette. ${ }^{94}$

\footnotetext{
${ }^{84}$ MNL BML IX.705 sz. n./1943 10.

${ }^{85}$ MNL BML IX.705 sz. n./1943 12.

${ }^{86}$ MNL BML IX.705 sz. n./1943 13.

${ }^{87}$ MNL BML IX.705 sz. n./1943 14-16.

${ }^{88}$ MNL BML IX.705 sz. n./1943 17.

${ }^{89}$ MNL BML IX.705 sz. n./1943 19.

${ }^{90}$ MNL BML IX.705 sz. n./1943 24-25.

${ }^{11}$ MNL BML IX.705 sz. n./1943 26.

92 MNL BML IX.705 sz. n./1943 27.

${ }^{93}$ MNL BML IX.705 sz. n./1943 28.

${ }^{94}$ MNL BML IX.705 sz. n./1943 29-37.
} 


\subsection{A sötétség ideje (1944)}

1944 szeptemberében, amikor a Pécsi Közjegyzői Kamara évi rendes közgyűlését meg kellett volna tartani, Magyarország már mintegy fél éve náci megszállás alatt állt, túl volt a vidéki zsidóság gettósításán és deportálásán, és közeledett a keleti front. Ilyen körülmények között a közgyűlés elmaradt.

\subsection{Az új korszellemhez igazodva (1945)}

Az 1945. szeptember 23-i közgyülésen a Pécsi Közjegyzői Kamara tagjai közül csupán Angyal Béa pécsi, Illgenn Aurél dombóvári, Köszeghy Antal szentlőrinci, Májay Dęsső kaposvári, Sziráky Lász̧ló pécsi, Szlávi Kornél mohácsi és Vargha Pál siklósi közjegyzők, valamint vitéz Bernáth Jenö tabi, vitéz. Rajnai Károly bajai, Csolosz Jenó nagykanizsai, Késmárky Aladár pécsi és Vékeony Béla szintén pécsi közjegyző-helyettesek vettek részt, miközben távolmaradását az összes meg nem jelent tag kimentette. ${ }^{95}$

Az elnöki nyitóbeszédben Angyal hosszan méltatta a közjegyzők tevékenységét, akik miközben „,hazánk hadsఇintér lett” - az irodák felszerelését és az okmánytárakat ért károk ellenére is a helyzet magaslatán álltak. „Az immár 70 éve életre bivott közjegyzői intézmény ezen súlyos idókben is kiállotta a türpróbát s megmutatta, hogy milyen fontos része hazánk jogéletének". ${ }^{96}$ A köztörténeti események és a politikai változások értékelése ebben az évben teljes egészében kimaradtak a nyitóbeszédből. Ezek helyett Angyal immár kizárólag a közjegyzői tevékenységet érintő témákra (elsősorban a közjegyzői hatáskör kérdésére) koncentrált.

A kamarai jelentést ezúttal Siklósi Tamás távolmaradása miatt maga az elnök olvasta fel. A jegyzőkönyvből ebben az évben derült ki először, hogy a jelentést ki szövegezte (ezúttal Siklósi).

„Örömmel állapitjuk meg, hogy az éveken át dúlt világégés befejezódött, szomorú szivivel látjuk ažt a mérhetetlen pusztulást, amelyet ez a reánk kénysžerített háború hazánkera zúdított’. Felettébb meglepi a megsárgult, poros irat olvasóját ez a megfogalmazás: „reánk kényszeritett báborü’. Lehet, hogy még nem telt el kellő idő az 1938 és 1941 közötti jegyzőkönyvek olvasásától ahhoz, hogy elfelejtődjön az akkori lelkesedés és az örömmámor szavai.

Sikelósi a Mindenható segítségét kérte „, a haza minden egyes polgárának, igy a magyar közjegyzớknek is, hogy mielöbb ujjá épithessüle eqt a sokat szenvedett Magyarorsqágot”. ${ }^{97}$ A jelentés beszámolt arról, hogy a kamarai évben a megszállás következtében csak néhány napra szünetelt a kamarai munka, majd némi önigazolás következett: „Öntudatunkat jelentős mértékben növeli az a változatlan megbecsülés és bizalom, melynek. karunk ma épp úgy a részese, mint volt a múltban. Ez kétség kivül annak a jele és legékesebb bizonyitéka, hogy mi ežlött is jó úton jártunk. De nem is járbattunk. belytelen utakon, mert mi, akik az egyszerü emberek ügyes-bajos dolgait intézz:̈̈k mindenkor nagy megértéssel, türrelemmel és jóakarattal, a munkás néppel való ezen szoros kapcsolatunknál fogva is csak szociális érzületü, demokratikus gondolkodású és magatartású közhivatalnokok.ká válhattunk (...). Joggal hihetjük tehát ezek után, hogy az uj, demokratikus Magyarország az.

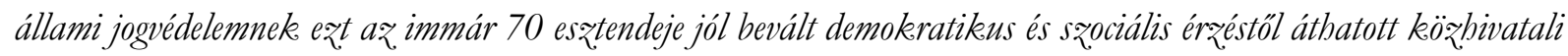

\footnotetext{
95 MNL BML IX.705 263/1945 1.

96 MNL BML IX.705 263/1945 2.

${ }^{97}$ MNL BML IX.705 263/1945 3.
} 
intézményét nemosak fenntartani és támogatni, hanem böviteni és igy továbbfejlesz̨teni igyekszik". ${ }^{98}$ Érdekes, hogy ez az első közgyúlési jegyzókönyv 1938 óta, melyben a demokratikus gondolkodás és a szociális érzék kifejezés előfordult. Természetesen nem vonható kétségbe, hogy ezek a vonások korábban is megvoltak a kamara tagjaiban, de arra érdemes felfigyelni, hogy a retorika jelentősen megváltozott a - vesztes - háború után.

A jelentésíró köszöntötte az ideiglenes nemzeti kormány új (második) igazságügyi miniszterét, Ries Istvánt, majd a kamarán belüli személyi változásokra tért rá. „Szomorú szívvel” emlékezett meg név szerint az elhunyt közjegyzőkről, majd felsorolta azokat is, akik hollétéről nem volt információ.

Ezek után külön szólt Krausz, Gyỡoő mohácsi közjegyzőről, akiről szintén nem tudtak semmit, de „a zisidótörvények hatálytalanitása folytán az ö állás(át) nem tekint(ettéke) megüresedettnek”. Itt a jelentés a „sajnos” szót nem használta, csak tárgyilagosan közölte, hogy Szkladányi László mohácsi közjegyző-helyettes holléte sem ismert, „akit a kamara a dr. Krausz. Gyöző kinevezéséneke hatálytalanitása folytán megüresedett mohácsi közjegyzői hivatalba rendelt ki helyettesüP’. ${ }^{99}$ Mivel a Magyar Közlöny szerint Krauszt 1943. november 23-tól kellett helyettesíteni ${ }^{100}$, világos, hogy a mohácsi közjegyzőt ${ }^{101}$, aki 1938 óta minden közgyűlésről távol maradt, az 1943-as kamarai évben fosztották meg hivatalától. A formálisan megüresedett közjegyzői állásra pályázatot írtak ki, de - mivel kinevezésre nem került sor - helyettesről kellett gondoskodni. Biztosra vehető, hogy Krauszt ${ }^{102}$ is az 1944. május 6. és 9. között felállított mohácsi gettóba ${ }^{103}$ zártak a többi helyi zsidóval együtt. A gettót ez év június 29 -én számolták fel, és kezdték meg a deportálást Auschwitzba ${ }^{104}$, ahonnan az ekkor már 82 éves, három évtizednyi ügyvédi ${ }^{105}$, majd két évtizednyi közjegyzői tapasztalattal rendelkező férfi nem tért vissza. ${ }^{106}$ Amennyiben a Dunántúl c. folyóirat 1944. július 2-i lapszámában a hírrovat információja pontos volt, a Pécsi Közjegyzői Kamarának ő volt az egyetlen zsidó tagja. ${ }^{107}$ Az irodai alkalmazottak vallására vagy származására nézve nem maradt fenn forrás.

A jelentés a személyi változások után az Ideiglenes Nemzeti Kormány igazságügyi miniszteréhez és pénzügyminiszteréhez intézett felterjesztéseket ismertette, míg a korábbi (nyilas) kabinet minisztereihez intézett felterjesztéséket érdekes módon nem tartotta érdemesnek arra, hogy a jegyzőkönyvben feljegyezzék őket. Az előbbiek közül említésre méltó a következő, igazságügyi

\footnotetext{
${ }^{98}$ MNL BML IX.705 263/1945 3-4.

${ }^{99}$ MNL BML IX.705 263/1945 5.

${ }^{100}$ Krausz Győ́ốt 1943. november 23-tól Apáthy Árpád helyettesítette. Lásd Magyar Közlöny, 1946. február 3. 28.

${ }^{101}$ Krausそ, aki 1862-ben Gyönkön született Krausz. Simon és Weltmann Róza házasságából, 1918-ban tagja volt a Mohácsi Nemzeti Tanácsnak. 1922-től volt közjegyző, miközben 1925 és 1939 között virilis képviselőként illetve 1940-től a Mohácsi Nemzeti Kaszinó választmányának tagjaként ,elókelő szerepet” vitt a város társadalmi életében is. Lásd ÚJVÁRI, Magyar Zsidó Lexikon 610. valamint Vörös István Károly közlése.

102 Krausz és felesége, Wurm Leontin mohácsi lakosok (Mohács, Kossuth u. 52.) számára „háborúban távollevớként“ gondnokot rendeltek ki. A szerző köszönetet mond Vörös István Károly történésznek, aki Krausz Gyózóó életrajzi adatait helytörténeti forrásokból összegyűjtotte és a szerző rendelkezésére bocsátotta.

${ }^{103}$ K. FARKAS, A mohácsi gettózás 2.

104 K. FARKAS, A mohácsi gettózás 9.

105 Krausz Győ́ớ 1890-ben nyert felvételt sásdi székhellyel a Pécsi Ügyvédi Kamarába. Lásd Pesti Hírlap, 1890. június 20. 11.

106 ROMVÁRY, Memento mori 125-134.

107 A hírrovat egy kerékpárlopásról és tíz fajtyúk ellopásáról szóló beszámoló között, vastagon szedve tette közzé, hogy „Baranyában egy zsidó kö̋jegyző volt”. Lásd Dunántúl, 1944. július 2. 6.
} 
miniszterhez intézett felterjesztés: „(...) szülkségesnek tartjuk, hogy reámutassunk arra, hogy a német nemzetiségi vidéken müködö körjegyzöink a német nemzetiségü lakosság hagyatéki ügyeinek elintézésében szinte minden tájékozódás nélkül állanak annyival is inkább, mert ök sem a vagyonelkobzásokról, sem az örökhagyók illetve örököseiknek haحához bü vagy fasiszta magatartásáról feltétlenül megbiz̧ható és hiteles értesitést nem kapnak. Ennek a követkęménye a százakra menö elintézetlen, függöben tartott hagyatéki ügy, melyböl mérhetetlen anyagi kára van az illetö közjegyzónek.”"108 A jelentést Siklósi azzal zárta, hogy „a jó Isten áldását kérte a Magyar Hazára". ${ }^{109}$

Az ügyforgalomról adatot nem közöltek eben az évben. A kamarai számadáson és a következő évi költségvetés elfogadásán túl már csak a tisztújításról számolt be a jegyzőkönyv: a pécsi kamara élére - miután Angyal döntést hozott arról, hogy fiatalabb kollégáira hagyja az elnökséget - Siklósi Tamást választották meg 19-ből 19 szavazattal, melyből hetet személyesen adtak le, tizenkettőt postán küldtek be. A közgyưlést az új elnök - az új korszellemhez igazodva - minden pátosz nélkül, egyszerűen berekesztette. ${ }^{110}$

\section{Következtetések}

A Pécsi Közjegyzői Kamara évi rendes közgyűléseinek jegyzőkönyveiből világos képet kapunk arról, hogy a kamara elnöke, a kamarai jelentés készítője és a közgyűlésen (az elnöki nyitóbeszéddel vagy a jelentéssel szemben ellenvélemény megfogalmazása nélkül) részt vevő tagok a köztörténeti illetve politikai eseményekre 1938 és 1942 között a kormányzat iránti feltétlen lojalitás jegyében reagáltak. Az „országgyarapitó bölcs kormányzót” és a „németek nagy vezérét’méltatva elsődlegesen egy célra koncentráltak, a magyarság számára megalázó trianoni békediktátum következtében előállt területvesztés minél szélesebb körû orvoslására. Ezzel a „,bármely áldozatot” megérô célkitűzéssel magyarázható az a minden józanságot nélkülöző álláspont, hogy a visszacsatolt területek „Nagymagyarország feltámadását’ fogják eredményezni, és a 2. magyar hadsereg Don-vidéken történt bevetése nem más, mint egy „ösmagyar földön vívott, határvédő háború”.

Hogy hogyan lehetett a polgári kori jogegyenlőségen alapuló jogeszményt elfelejteni a jogkorlátozó törvények és rendeletek alkalmazásakor, melyekkel a közgyúlések alkalmával csak a közjegyzői tevékenységet közvetlenül érintő jogtechnikai részletek tekintetében foglalkoztak? A jegyzőkönyvekből nem derül ki, hogy a zsidósággal szemben volt-e kulturális, vallási vagy ún. faji elő́télet, esetleg ellenérzés is e mögött a tárgyilagos viselkedés mögött, de mindennek nem is lehet jelentősége akkor, ha a jogász feltétel nélkül elkötelezett a természetjog és az erkölcs mellett. Ha azonban csupán a pozitív jogi normák végrehajtására köteles közhivatalnoknak tekinti önmagát, nem a társadalom felelős tagjának, akkor valóban csak a pont hiányát veszi észre az „i” betűn, de az „i” betű jelentésével nem foglalkozik.

Más kérdés, hogy az igazságügyi miniszterhez intézett kamarai felterjesztések vagy a közgyűlési felszólalások hatékony eszközök lehettek-e volna a lépcsőzetes jogkorlátozással szemben. Egyrészt Angyal Béla 1943 szeptemberi elnöki nyitóbeszédéből világosan kiderült, hogy a felterjesztések rendszerint érdemi válasz nélkül maradtak és a közjegyzői intézményt fojtogatta a

108 MNL BML IX.705 263/1945 8.

109 MNL BML IX.705 263/1945 10.

110 MNL BML IX.705 263/1945 11-19. 
politikai függés, amely elsősorban a kinevezési gyakorlatban és a közjegyzői hatáskörök korrekt rögzítésének hiányában nyilvánult meg. Másrészt a közgyűlési felszólalásoknak csak a jelenlévők véleményét formáló hatása lehetett volna, erről az eszközről azonban lemondtak vagy nem is tartották szükségesnek, hogy éljenek vele.

Ha a közgyúléstől távolmaradtak névsorát vizsgáljuk, abban évről évre folyamatos változás figyelhető meg; csupán Krausz Gyớoón volt az, aki 1938 és 1945 között egy alkalommal sem vett részt a kamarai rendezvényen. Ezért megdőlni látszik az, a kutatás első felében megfogalmazott vélelem, hogy a távolmaradás a politikai ellenvélemény megnyilvánulása lehet. A kamarán belül vetődött fel a zsidónak minősülő magyar állampolgárok differenciált adóztatásának javaslata, sőt Krausszal szemben tagtársai (nyilvánosan) nem fejezték ki támogatásukat a fokozatos jogkorlátozáskor, majd hivatalától történt megfosztásakor és nem adtak hangot sajnálatuknak sem, amikor a háború végén nem tért vissza Pécsre.

Végezetül le kell vonni az 1945. évi közgyúlési jegyzőkönyvből azt a következtetést, hogy az Ideiglenes Nemzeti Kormány (1944. december 22. - 1945. november 15.) felállítását követően a kamara azonnal igazodott az új korszellemhez. A kamara vezetésében generációváltást hajtottak végre, valamint a közjegyzők demokratikus meggyőződését és szociális érzékenységét hangsúlyozták abban a reményben, hogy az intézmény megőrzi jelentőségét a háború utáni - újra csonka - Magyarországon is.

\section{Felhasznált források és irodalom}

Magyar Nemzeti Levéltár Baranya Megyei Levéltára (MNL BML) IX.705 A Pécsi Közjegyzői Kamara iratai, közgyűlési jegyzőkönyvek

Pesti Hírlap, 1890. június 20-i lapszám

Magyar Közlöny, 1946. február 3-i lapszám

Dunántúl, 1944. július 2-i lapszám

CsILlag Attila - RoKolya Gábor: A Pécsi Közjegyzői Kamara története 1875 - 1949. Budapest 2015

JUHÁSz Gyula: Uralkodó eszmék Magyarországon 1939 - 1944. Budapest 1983

KARSAI László: A magyarországi zsidótörvények és rendeletek 1920 - 1944. In: MOLNÁR Judit (szerk.): A holokauszt Magyarországon európai perspektívában. Budapest 2005, 140-163.

K. FARKAS Claudia: A mohácsi gettózás.

http://www.publikon.hu/htmls/tanulmanyok.html?ID=41\&essayID=518 (letöltve: 2018. 07. 01.)

NAGY Péter Tibor (szerk.): Magyar Zsidó Lexikon. Javított és 1948-ig bővített digitális kiadás 2006, http://mek.niif.hu/04000/04093/html/

ROKOLYA Gábor: A polgári közjegyzőség emlékezete 1875 - 1949. Budapest 2009

ROMVÁRY Ferenc: Memento mori Pécs - Baranya. Pécs 1999

SZITA Szabolcs: Halálerőd. A munkaszolgálat és a hadimunka történetéhez 1944 - 1945. Budapest 1989

ÚJVÁRI Péter (szerk.): Magyar Zsidó Lexikon. Budapest 1929 